\title{
Araştırmacı Öğretmenin Desteklenmesi: Bir Durum Çalışması *
}

\author{
Sibel Akın ${ }^{* * 1}$ ve Gizem Solmaz ${ }^{2}$
}

$\ddot{O} z$

Anahtar Sözcükler

Bu araştırmanın amacı 2006 yılı veya sonrasında kurulmuş Türkiye'deki çeşitli üniversitelerin eğitim fakültelerinde lisansüstü öğrenimlerine devam eden öğretmenlerin bilimsel araştırma bilgi, beceri ve tutumlarının geliștirilmesini amaçlayan bir proje bağlamında, projenin eğitim alanında araştırma yapmak için gerekli temel nitelikleri ne düzeyde geliştirdiğini katılımcıların bakış açılarına dayalı olarak incelemektir. Nitel araştırma desenlerinden durum çalışması olarak tasarlanan bu araştırmanın örneklemini amaçlı örnekleme yöntemlerinden ölçüt örnekleme ve maksimum çeşitlilik örneklemesi ile seçilen ve araştırmanın gerçekleştirildiği projede yer alan 27 katılımcı oluşturmuştur. Veriler yüz yüze gerçekleștirilen beș odak grup görüșmesi ile toplanmıș ve verilerin analizi içerik analizi yöntemi ile gerçekleştirilmiş̧ir. Araştırmadan elde edilen bulgular katılımcıların bu eğitimi etkili bulduklarını ve projenin bilgi, beceri ve tutum-inanç olmak üzere üç temel boyutta kendilerinin bilimsel araștırma yapma yeterliklerini çeşitli açılardan geliştirdiğini ortaya koymuştur. Bu bakımdan, araştırmadan elde edilen sonuçlar hizmet öncesi öğretmen eğitiminde, hizmet içi öğretmen eğitiminde ve lisansüstü eğitimde bireylerin bilimsel araștırma becerilerinin güçlendirilmesine ıșık tutabilecek öneriler sunmaktadır.

\author{
Öğretmen eğitimi \\ Araştırmacı öğretmen \\ Bilimsel araştırma \\ yeterlikleri \\ Durum çalışması \\ Makale Hakkında \\ Gönderim Tarihi \\ 7 Temmuz 2019 \\ Kabul Tarihi \\ 24 Aralık 2019 \\ Makale Türï \\ Araştırma Makalesi
}

DOI: $10.12984 /$ egeefd.588166

\section{Empowering Teachers As Researchers: A Case Study ${ }^{*}$}

\section{Abstract}

Keywords

The purpose of this study is to investigate how well a project that aimed to develop scientific research competencies of teachers who were also graduate students in the faculties of education at different universities - those established in 2006 or later in Turkey - was conducive to develop the knowledge, skills, and attitudes that are considered as essential for the process of carrying out research in education, as perceived by participating teachers. Designed as a qualitative case study, the sample involved 27 participants who had been selected for the project through criterion sampling and maximum variation sampling strategies. The data were collected through five semi-structured face-to-face focus group interviews and analyzed by content analysis method. Considering the findings of the study, the participants articulated that they found this training effective and the project helped them improve their scientific research competencies in three dimensions: (1) knowledge, (2) skills, and (3) attitudes-beliefs. In light of the findings, the present study offers essential implications to pre-service teacher education, inservice teacher education, and graduate education for developing the scientific research competencies of individuals more effectively.

Teacher education

Teacher as researcher

Scientific research

competencies

Case study

Article Info

Received

July 7, 2019

Accepted

December 24, 2019

Article Type

Research Paper

Atıf: Akın, S. ve Solmaz, G. (2019). Araştırmacı öğretmenin desteklenmesi: Bir durum çalışması. Ege Eğitim Dergisi, 20(2), 383-401. doi: $10.12984 /$ egeefd.588166

* Bu çalışma, TUBİTAK tarafından desteklenen 2237-A kodlu Ĕğitim Alanındaki Lisansüstü Öğrenciler İçin Bilimsel Araştırma Becerilerinin Geliştirilmesi başlıklı proje kapsamında gerçekleştirilmiştir. [This study was conducted as part of a 2237-A project titled Developing Scientific Research Competencies of Graduate Students in Faculties of Education and was granted by the Scientific and Technological Research Council of Turkey (TUBITAK).]

* Bu çalıșma, 03-06 Eylül 2019 tarihleri arasında Hamburg/Almanya'da düzenlenen ECER (European Conference on Educational Research) Konferansında sunulmuştur [The study was presented at the European Conference on Educational Research (ECER) in Hamburg/Germany, September 03-06, 2019].

${ }^{* *}$ Sorumlu Yazar/Corresponding Author

1 (D) TED Üniversitesi, Eğitim Fakültesi, Türkiye, sibel.akin@tedu.edu.tr

2 (D) TED Üniversitesi, Eğitim Fakültesi, Türkiye, gizem.solmaz@ tedu.edu.tr 


\section{Extended Abstract}

\section{Introduction}

The disconnect between practice and educational research has been a long-standing issue among researchers, practitioners, and policymakers (Broekkamp \& van Hout-Wolters, 2007; McIntyre, 2005; Vanderlinde \& van Braak, 2010). For example, Lytle and Cochran-Smith (1992) indicate that implicit in the disconnect is a theory of knowledge for teaching that privileges university researchers' knowledge over teachers. Ironically, at the same time, blaming teachers for education systems' downfalls has reinforced the argument that teachers should be the strongest agents in education based on their daily professional decision making. Therefore, although educational research should inform policy and practice (Broekkamp \& van Hout-Wolters, 2007; McIntyre, 2005; van Zee, 1998), few teachers would argue that their teaching practice is largely informed by educational research (Cochran-Smith \& Lytle, 1990; Korthagen, 2007, McIntyre, 2005). Hence, many teachers see research and practice as separate, and subsequently believe in a low impact of teacher education (Korthagen, 2007). However, teachers should be producers of research rather than consumers of research (Robinson, 2003). Incorporating teachers as researchers as a stance is an impactful form of professional development (Iliško, Ignatjeva, \& Mičule, 2010; Robinson, 2003) that offers much to teaching as a profession (Cochran-Smith \& Lytle, 1999). Contrary to expecting teaching to be stable and predictable, teachers as researchers could initiate school-based educational changes. Moreover, teachers' questions and investigations may offer more practical implications to other teachers than university-based researchers' inquiries (McIntyre, 2005; van Zee, 1998). Therefore, teachers, as reflective practitioners, must actively take place in the educational realm and carry out research to make informed decisions, improve their teaching practices, and identify the educational issues in their classrooms more effectively, which also offers a way beyond alienation (Iliško et al., 2010). In empowering teacher research as a "systematic and intentional inquiry carried out by teachers" (Cochran-Smith \& Lytle, 1990, p. 3), this study used the data from a project sponsored by the Scientific and Technological Research Council of Turkey. The project aimed to develop the scientific research competencies of teachers who were also graduate students in the faculties of education at different universities in Turkey. In particular, the study sought to address the following research question: What essential knowledge, skills, and attitudes was this project conducive for carrying out educational research, as perceived by participating teachers? In so doing, this study builds and extends on the research that empowering teachers as researchers indicates an enlarged view of the teacher's role such as a decision maker, consultant, curriculum developer, analyst, activist, and school leader (Cochran-Smith \& Lytle, 1999).

\section{Method}

The study employed case study design which investigates a phenomenon (the case) within its real life context using empirical inquiry (Yin, 2014). In this respect, the study was carried out within the context of a project that sought to develop the scientific research competencies of teachers, and funded by the Scientific and Technological Research Council of Turkey (TÜBİTAK). Among purposive sampling strategies (Patton, 1990), the sample of the study was, first, selected through criterion sampling and it was ensured that all participants were pursuing their graduate education at newly established universities in Turkey - specifically those founded in 2006 or later - as there has been much debate over these recent institutions, coupled with the argument that the quality of the teacher education offered by these universities might be poor due to their inadequate infrastructure in many regards. Second, using maximum variation sampling, the participants were chosen to ensure a wide variety of characteristics such as studying a master's or Ph.D. degree, the universities that they have been studying at and the graduate programs that they enrolled in given that these characteristics maximize the diversity relevant to the research question while they may also allow for identifying the common patterns that emerge out of diversity (Patton, 1990). As a result, the sample included 27 teachers and the data were collected by semi-structured face-to-face focus group interviews (Marshall \& Rossman, 2011) for which an interview schedule was developed by the researchers. After taking the opinions of experts and piloting the instrument, 5 focus group interviews were conducted, each of which took 55 to 65 minutes. Having obtained the interviewees' permission, the focus group interviews were audio-recorded and transcribed verbatim. For the data analysis, the study employed content analysis method, wherein the text data have been coded into broader categories based on the identified common patterns (Bogdan \& Biklen, 2007; Patton, 1990). To that end, NVivo 10 was used to code the transcripts. Lastly, multiple strategies were employed to ensure the credibility, dependability, transferability, and confirmability of the study for establishing trustworthiness. 


\section{Findings}

Considering the findings of the study, the participants articulated that they found this training effective and the project helped them improve their scientific research competencies in three dimensions: (1) knowledge, (2) skills, and (3) attitudes-beliefs. First, most participants articulated that the project helped them expand their knowledge on the nature of research and the basics of educational research, identifying the research problem, ethics in research, locating and reviewing the literature, research methods and designs, sampling strategies, data collection, data analysis, data analysis softwares, reporting the findings, writing a proposal, different types of research projects, and the primary resources for research in education. Second, a large number of participants expressed that they, first and foremost, had an opportunity to develop skills in planning a scientific research effectively and systematically, and in writing a research proposal. Moreover, almost all participants stated that the project supported them well to advance their skills in using quantitative/qualitative data analysis softwares. In addition to these, many participants addressed that the project provided them with the opportunity to develop critical and creative thinking skills. Lastly, as for attitudes-beliefs, a significant number of participating teachers clearly mentioned that the project helped them develop positive attitudes towards carrying out scientific research. In this respect, many participants said that the project primarily enabled them to recognize the importance of planning and conducting well-planned and systematic scientific research. Many participants further highlighted the impact of the project on increasing their self-efficacy as a researcher in several regards, especially in developing a research proposal. The participating teachers also acknowledged the role of this project in supporting them to develop positive attitudes towards ethics in research, data analysis, the use of data analysis softwares, and the integration of information technologies in research. Except these, most participants said that the project especially enabled them to develop a global perspective, as well as an interdisciplinary perspective in research. Lastly, it was seen that a large number of the participants considered the instructors taking part in the project as effective role models and developed certain attitudes, such as having high professional competence in and holding positive attitudes towards scientific research, being open to communication, providing effective guidance on research, and keeping themselves up-to-date with the latest developments in educational research. The study further pointed to different sources that had an influence on the effectiveness of the project. To illustrate, many participants addressed the importance of group work and practice-based opportunities throughout the project, which, as they stated, supported the development of knowledge and skills that they acquired. Similarly, they articulated that learner-centered environment raised their interest and motivation towards the courses and thereby, increased the effectiveness of instruction significantly. Moreover, it was seen that some participants expressed a desire for the arrangement of physical environment in a way that it would facilitate more interaction in the classroom and in group work. Lastly, a significant number of participants mentioned that they found technology enhanced learning in this project effective, particularly in terms of using different softwares in data analysis and literature review.

\section{Discussion and Conclusion}

In light of the findings, the present study offers essential insights to pre-service teacher education, in-service teacher education, and graduate education for developing the scientific research competencies more effectively. To this end, the study first offers several implications for teacher educators to implement the scientific research methods courses - offered in pre-service teacher education and graduate education - in an environment where the process of learning is enhanced by group work, active learning methods, hands-on activities, and technologysupported practices. In addition, the present study offers suggestions especially for the faculties of education in the universities that were established in 2006 or later in Turkey. Accordingly, the study points out that the teacher educators offering such courses must be competent at conducting scientific research, have good communication skills to interact effectively with teacher candidates/graduate students, and provide quality guidance to them on how to develop scientific research competencies. Besides, the study has the implications of highlighting the need for improving infrastructure of the faculties of education in those newly established universities to increase the quality of the courses that are offered to develop teacher candidates'/graduate students' scientific research competencies. The current study might also provide significant implications for policymakers in the Council of Higher Education (CHE) to reconsider the weekly allocated time, objectives, and content of the Research Methods in Education course as it has been offered as a theoretical course in teacher education programs to be implemented in two hours in a week, which thereby may not leave enough room for practice. Lastly, the results of this study might shed light into in-service teacher education for developing effective in-service trainings for teachers to empower them as researchers. 


\section{Giriş}

Günümüzde bireylerden sahip olmaları beklenen niteliklerin değişmesi ile çağın getirdiği ihtiyaçlara cevap verebilecek nitelikteki insan gücünü yetiştirmek ve eğitim çıktılarının niteliğini iyileştirmek üzere birçok ülkede çeşitli eğitim reformları yapılmaktadır. Araştırmalar, eğitim çıktılarının niteliğini etkileyen en güçlü değişkenlerden birinin öğretmen niteliği olduğunu gösterdiğinden (Darling-Hammond ve Sykes, 2003; DarlingHammond ve Youngs, 2002; Day, 2013; Goldhaber, 2007; Hanushek ve Rivkin, 2010; Nye, Konstantopoulos ve Hedges, 2004; OECD, 2005; Rice, 2003; Wayne ve Youngs, 2003) gerçekleştirilen reformların başarılı sonuçlar vermesi öncelikle yüksek nitelikli öğretmenlere bağlıdır (Darling-Hammond, 2010; Gopinathan vd., 2008). Bu bakımdan, yalnızca öğrenenlerin değil öğretmenlerin de 21. yüzyılın gerektirdiği nitelikleri kazanması geleceğin öğrencilerini yetiştirebilmeleri için büyük bir önem taşımaktadır.

Birçok ülkede olduğu gibi Türkiye'de de geçmişten günümüze öğretmen eğitimi sisteminin iyileştirilmesi ile ilgili çeşitli yeniden yapılandırma çalışmaları gerçekleştirilmiştir. Özellikle son 30 yıl içerisinde hız kazanan bu reformların arka planında ise öğretmen eğitimi programlarına getirilen eleştiriler ve bunun sonucunda yükselen nitelikli öğretmen eğitimi arayışı bulunmaktadır (Çakıroğlu ve Çakıroğlu, 2003; Yıldırım, 2011). Öğretmen niteliğini artırmak amacıyla ülkemizde öğretmen eğitimi sistemi 1970'li yıllardan itibaren öğretmen okullarından eğitim enstitülerine ve 1982 yılında gerçekleştirilen yeniden yapılanma sonucunda ise enstitülerden üniversitelere aktarılmıştır. Bu durum, esasında öğretmen eğitimi arayışındaki niteliğin bilimsel araştırma sonuçlarına ve çağdaş yaklaşımlara dayalı olarak iyileştirilmesi için önemli bir firsat olmuştur. Ancak bu süreçte benimsenen kuramı ön plana alan ve uygulamadan gittikçe uzaklaşan bakış açısının egemen olmasıyla bu yapılanma girişimlerinin öğretmen eğitimi niteliğine ne düzeyde katkı sağladığ 1 hep tartışılmış ve nitelik kaygısının geri planda kalmasına neden olmuştur (Yıldırım, 2011). Öğretmen eğitimi sisteminin ve öğretmen niteliğinin özellikle hizmet öncesi öğretmen eğitimi yoluyla iyileştirilmesi amaçlandı̆̆ için benzer şekilde öğretmen eğitimi programlarında da sık sık değişiklikler yapılmaktadır. Öte yandan, bu değişikliklerin genellikle tepeden aşağı bir yaklaşımla ve sürekliliği olmayan bir biçimde gerçekleştirildiği, belirli bir kavramsal çerçeveden bağımsız ve öğretmen eğitimine yön veren yaklaşımlar ile bilimsel araştırma sonuçları göz önünde bulundurulmadan yapıldığı eleştirilmektedir (Aydın, Şahin ve Topal, 2008; Azar, 2011; Çakıroğlu ve Çakıroğlu, 2003). Bunların sonucunda ise, süregelen yeniden yapılandırma çalışmaları içerisinde önemli çatışma alanları ve çelişkiler oluşmaktadır (Yıldırım, 2011, 2013).

Öğretmen eğitimi konusundaki yaklaşımların ve gerçekleştirilen tüm yeniden yapılandırmaların temelinde eğitim ve ögretimle ilgili benimsenen belirli varsayımlar ve eğitim felsefeleri bulunur; eğitim felsefelerine ise inançlar bütünü olarak tanımlanan ve öğretmen eğitimi ile ilgili uygulamaların analiz edilmesini sağlayan paradigmalar yön vermektedir (Yıldırım, 2011). Ülkemizdeki öğretmen eğitimi sisteminde gerçekleştirilen yeniden yapılanmaları belirli çatışma alanları çerçevesinde farklı eğitimcilerin önerdikleri paradigma sınıflamalarına (Becker, Kennedy ve Hundersmarck, 2003; Cochran-Smith ve Fries, 2008; Elliot, 1993; Long ve Riegle, 2002; Zeichner, 1983) göre analiz eden Yıldırım (2011) Türkiye'de öğretmen eğitimi sisteminde öğretmen kavramına yüklenen anlamın konu alanı uzmanlı̆̆ını ön plana çıkaran bir yapıda olduğunu ve öğretmenliği alan bilgisi odaklı anlayışa indirgediğini tartışmaktadır; bunun yanı sıra, Türkiye'de öğretmen eğitimi sisteminde kuram temelli anlayışın hâkim olduğunu ve bu durumun öğretmenliğin kavramsal boyutu ile kuramsal temelini ön plana çıkardığını belirterek uygulama odaklı öğretmen eğitiminden giderek uzaklaşılmakta olduğunu ifade etmekte, günümüzde hızla önem kazanan sorun çözme ve karar verme gibi öğretmenlik becerilerinin altını çizen uzman ögretmen anlayışının yerine, ülkemiz öğretmen yetiştirme sisteminde hâlen teknisyen öğretmen anlayışının benimsendiğini vurgulamaktadır.

Öğretmen eğitiminde günümüzde önemi giderek ön plana çıkan eleştirel düşünme, yaratıcılık, karar verme, işbirliği, iletişim ve araştırma becerilerinin geliştirilmesi oldukça önemlidir. Bilim ve teknoloji alanındaki gelişmeler, bilgiyi yalnızca zihninde depolayan bireyler yerine bilgiyi araştıran, sorgulayan, analiz eden ve sonuçlar çıkarabilen bireylerin yetiştirilmesinin gerekliliğini ve bilimsel araştırma sürecine ilişkin temel bilgi, beceri ve tutum özelliklerinin kazandırılmasının önemini vurgulamaktadır (Metin, 2015). Bu çerçevede, ulusal ve uluslararası alanyazında, anayasada, eğitimle ilgili yasalarda ve öğretim programlarında öğretmenlerin öğretim dişında başka temel görevlerinin de olduğu vurgulanmakta ve bu açıdan öğretmenlerin özellikle araştırma yapabilme bilgi, beceri ve tutumuna sahip olmalarının 21. yüzyılda kazanmaları gereken en önemli niteliklerden birisi olduğu belirtilmektedir (Büyüköztürk, Kılıç Çakmak, Akgün, Karadeniz ve Demirel, 2012). Öte yandan, Türk eğitim sisteminde genel olarak araştırma kültürünün yaygınlaştırılması yerine bilginin ezberlenmesini teşvik eden bir yaklaşımın egemen olduğu sıklıkla eleştirilmektedir. Araştırmalar öğretmen adaylarının ve öğretmenlerin yüksek düzeyde araştırma yapma bilgi, beceri ve tutumlarına sahip olmadıklarını, eğitim araştırmalarından yeterli düzeyde yararlanmadıklarını ve araştırma faaliyetlerine katılmadıklarını göstermektedir (Ateş, 2005; Büyüköztürk, 1997, 1999; Çepni ve Küęük, 2003; Küçük ve Çepni, 2005). Diğer taraftan, 2004-2005 yıllarında Millî Eğitim Bakanlığı (MEB) tarafından ilköğretimden başlamak üzere yapılandırmacı felsefeye dayalı olarak yenilenen öğretim programları öğrencilere araştırma kültürünün 
kazandırılmasının önemine işaret ederek (Büyüköztürk vd., 2012) teknisyen öğretmen yerine uzman öğretmen ihtiyacını vurgulamıştır (Yıldırım, 2011). Bu gelişmeye paralel olarak öğretmen yeterliklerinin güncellenmesi ve geliştirilmesi amacıyla MEB 2006 yılında öğretmenlik mesleği genel alan ve özel alan yeterliklerini yayımlamıştır. Genel alan yeterlikleri (MEB, 2006) kapsamında öğretmenlerin bilimsel araştırma yapmaya istekli olmaları, öğrenme-öğretme sürecini iyileştirmek ve okulun gelişimine katkı sağlamak için eylem araştırmaları yapmaları, veri analizi yapabilmeleri ve bunun için uygun istatistik tekniğini seçebilmeleri, bilgi ve iletişim teknolojilerini kullanabilmeleri gibi performans göstergeleri bulunmaktadır. Bu göstergeler, öğretmenlerin MEB tarafından araştırma kültürüne teşvik edilmeleri bakımından önem taşımaktadır.

$\mathrm{Bu}$ gelişmelere paralel olarak Yükseköğretim Kurulu (YÖK) tarafından yeniden yapılandırılan ve 2006-2007 eğitim öğretim yılından itibaren uygulamaya koyulan öğretmen eğitimi programlarına bilimsel araştırma yöntemleri dersi eklenmiştir. Ancak 1998 yılındaki yeniden yapılandırma ile benimsenen uygulama ağırlıklı yaklaşım yerine 2006 yılında gerçekleştirilen yeni düzenleme ile öğretmen eğitimindeki uygulama odaklı derslerin sayısı ve saati azaltılarak kuram odaklı kavramsal bilgiyi teşvik eden nitelik tanımına geri dönülmüştür. Öğretmen eğitiminde ağırlıklı olarak alan bilgisi ve kuram odaklı bir yaklaşımın benimsenmesi sonucunda ülkemizde eğitim alanında araştırma yapma kültürünün geliştirilmesi ve yürütülen araştırmaların niteliğinin yükseltilmesi için öğretmenlerin araştırma bilgi, beceri ve tutumlarının iyileştirilmesine hâlen büyük ölçüde ihtiyaç duyulmaktadır. Birçok araştırma öğretmen adaylarının veya öğretmenlerin araştırma bilgi, beceri, tutum (Biçer, Bozkırlı ve Er, 2013; Camuzcu Aşiroğlu, 2016; Cerit Berber, 2013; Ekiz, 2006; Ekiz ve Yiğit, 2012; Korkmaz, Şahin ve Yeşil, 2011; Küçükoğlu, Taşgın ve Çelik, 2013; Polat, 2014; Taşdemir ve Taşdemir, 2011; Yenilmez ve Ata, 2012) veya öz yeterliklerinin hâlâ yüksek düzeyde olmadığını (Korkmaz ve diğ., 2011; Nartgün, Uluman, Akın, Çelik ve Çevik, 2008), öğretmenlerin eğitim araştırmalarını gerektiği kadar takip etmediklerini (Ekiz, 2006; Sarı, 2006; Şahin ve Arcagök, 2013; Yıldırım, İlhan, Şekerci ve Sözbilir, 2014); eğitim araştırmalarının bulgularını sınıf içi uygulamalarını geliştirmek için yeterli düzeyde kullanmadıklarını (Cerit Berber, 2013; Sarı, 2006), uygulamaya yansıtılabilirliğini düşük bulduklarını (Ateş ve Yıldırım, 2015; Uçgun ve Ünal, 2015; Yıldırım, İlhan, Şekerci ve Sözbilir, 2014) ve öğretmenlik kariyerleri boyunca yeterli sıklıkta veya hiç araştırma yapmadıklarını (Ekiz, 2006; Şahin ve Arcagök, 2013) ortaya koymaktadır. Çeşitli araştırmalar ise (Akgün, 2012; Ayaydın ve Kurtuldu, 2010; Tomakin, 2007) öğretmen adaylarının lisans programlarına eklenen bilimsel araştırma yöntemleri dersine ilişkin tutum ve görüşlerinin dersin içeriği, işleniş biçimi, kullanılan ölçme değerlendirme teknikleri gibi çeşitli boyutlar açısından istenilen düzeyde olumlu olmadığını göstermektedir. Araştırma eğitiminin lisansüstü düzeyde dahi kurumsallaşamadığı ve bunlara paralel olarak çeşitli eğitim kademelerindeki öğrencilerin en yetersiz oldukları alanlar içerisinde de bilimsel süreç becerilerinin yer aldığı vurgulanmaktadır (Büyüköztürk vd., 2012). Tüm bu bulgular öğretmenlerin araştırma yapma bilgi, beceri ve tutumlarının geliştirilmesine yönelik ihtiyacı açıkça ortaya koymaktadır.

Diğer yandan, MEB tarafindan 2017 yılında güncellenen öğretmenlik mesleği genel yeterlikleri göstergeleri incelendiğinde araştırma yeterliği ile ilgili beklentilerin azaldığı ve öğretmenlerden yalnızca alanlarına ilişkin temel araştırma yöntem ve tekniklerini sınıflandırmalarının beklendiği dikkat çekmektedir (MEB, 2017). Son olarak 2018 yılında YÖK tarafından yeniden yapılandırılan öğretmen eğitimi programlarında da kuramsal bir bakış açısının baskın olduğu görülmektedir. Bunların bir yansıması olarak, uygulama odaklı bir vizyonun benimsenmeyişinin sonucunda geleneksel yaklaşımı yansıtan bu politikalar günümüz dünyasında başarılı sonuçlar vermemekte ve öğrencileri içinde bulunduğumuz çağın dönüşümüne hazırlayabilecek öğretmenler yetiştirilememektedir. Öğretmen adayları 21. yüzyılda nitelikli bir öğretmenden beklenen temel bilgi, beceri ve tutum özellikleri açısından önemli eksiklerle mezun olmakta ve benzer şekilde hizmet içi öğretmenler de güncel eğitim hedeflerini karşılayabilmek bakımından gerekli meslekî bilgi ve becerileri yeterli düzeyde geliştirememektedir (Çakıroğlu ve Çakıroğlu, 2003; Yıldırım, 2018). Bu açıdan, hizmet öncesi öğretmen eğitimi ile başlayan ve aşamalı olarak hizmet içi eğitim süreci ile devam eden meslekî gelişimleri boyunca, eğitim sistemlerinin başarılı sonuçlar vermesinde en önemli role sahip olan öğretmenlerin bu yeterlikleri kazanacak şekilde yetiştirilmesi büyük bir önem taşımaktadır (European Commission, 2013).

Eğitim alanında araştırma ve uygulama arasındaki ilişkinin yeterince güçlendirilmemiş olması uluslararası arenada da birçok araştırmacı, uygulayıcı ve politika geliştirici tarafından uzun bir süredir dile getirilmektedir (Broekkamp ve van Hout-Wolters, 2007; Hargreaves, 1995; McIntyre, 2005; Vanderlinde ve van Braak, 2010). Eğitim araştırmalarının temel rolü eğitim politikalarına ve uygulamalarına 1şık tutmak olsa da (Broekkamp ve van Hout-Wolters, 2007; McIntyre, 2005; van Zee, 1998), kuram ve uygulama arasındaki bu zayıf bağ sonucunda eğitim-ögretim ile ilgili uygulamalarında ve meslekî karar verme süreçlerinde bilimsel araştırma sonuçlarından sıkça yararlanan öğretmen sayısı oldukça azdır (Cochran-Smith ve Lytle, 1990; Crawford ve Adler, 1996; Korthagen, 2007, McIntyre, 2005). Bu durum, öğretmen eğitimi ve sınıf içi uygulamalar arasındaki bağın zayıflaması bakımından öğretmenlerde meslekî tatminsizlik yaratmakta ve memnuniyetsizliğe neden olmaktadır (Korthagen, 2007). 
Öğretmenlerin eğitim öğretim ile ilgili bilgi üretme süreçlerinde çoğu zaman çok az söz sahibi olması sebebiyle, sınıf içi uygulamaların iyileştirilmesi için öğretmenlerin meslek yaşamlarında izledikleri yöntemler veya onların bakış açısı ile tespit edilen problem durumları yeterince dile getirilememektedir (Cochran-Smith ve Lytle, 1990; Iliško, Ignatjeva ve Mičule, 2010). Yalnızca üniversite temelli akademik bilgiye değer veren bakış açısına alternatif olarak Lytle ve Cochran-Smith (1992) öğretmenlerin emik bir bakış açısıyla sınıf içi deneyimlerinden yola çıkarak belirleyecekleri sorularla yön verecekleri araştırmaların özgünlüğüne ve önemine işaret etmektedir. Diğer bir ifade ile geleneksel bakış açısının tersine, öğretmenler eğitsel araştırmaların yalnızca tüketicisi olarak değil aynı zamanda üreticisi olarak görülmelidir (Kincheloe, 2012; Robinson, 2003). Bu görüş, öğretmenleri bir teknisyen, tüketici, alıcı ve aktarıcı olarak görmek yerine bir karar verici, düşünür, danışman, program geliştirme uzmanı, analist, aktivist, sosyal değişim aracı ve lider olarak gören ve kökleri eleştirel kurama uzanan genişletilmiş bir öğretmen vizyonuna dayanmaktadır (Cochran-Smith ve Lytle, 1999).

Öğretmenlerin araştırma yapma bilgi, beceri ve tutumlarının desteklenmesi, meslekî yabancılaşmalarını önleme ve meslekî gelişimlerine katkıda bulunma açısından büyük bir öneme sahiptir (Iliško vd., 2010; Postholm, 2009; Robinson, 2003). Öğretmenliğin profesyonelleştirilmesi, nitelikli öğretmenin tek veya değiş̧mez bir tanımının olamayacağının anlaşılması, okul temelli tabandan yapılanmaların güçlendirilmesi ve öğretim programlarının iyileştirilmesi bakımından da öğretmenlerin araştırmacı olarak teşvik edilmeleri oldukça önemlidir (CochranSmith ve Lytle, 1998, 1999). Üniversitelerde gerçekleştirilen çalışmalara kıyasla öğretmenler tarafindan tespit edilerek araştırılan problem durumları daha pratiğe dönük sonuçlar ortaya koyabileceğinden eğitim öğretim süreçlerine ve diğer öğretmenlere 1şık tutabilir; bu açıdan araştırmacı öğretmenlerin desteklenmesinin öğretmen eğitimine sağlayacağı katk1 büyüktür (McIntyre, 2005; van Zee, 1998). Öğretmenlerin eğitim alanında araştırmacı olarak etkin bir rol almaları, meslekî yaşamlarında alacakları kararlarda araştırma sonuçlarından beslenerek fark yaratmalarına, öğretmenlik mesleğinin pratik boyutunu güçlendirmelerine, sınıf içerisindeki güncel eğitim öğretim ihtiyaçlarına daha etkili çözümler geliştirebilmelerine ve öğrenci çıktılarının niteliğini geliştirebilmelerine katkıda bulunabilir (Babkie ve Provost, 2004; Iliško vd., 2010). Ayrıca, bunun yalnızca okullardaki uygulamalara değil üniversitelerdeki araştırmacılar tarafindan gerçekleştirilecek çalışmalara da 1şık tutacağı açıktır (Cochran-Smith ve Lytle, 1993).

Öğretmenlerin kendi uygulamalarını inceleme, mevcut bir sorunu ya da öğretim süreçleri içinde ortaya çıkan bir durumu anlama ve olası çözümler üretmeleri için önerilen ve kuram ile uygulama arasındaki boşluğu doldurabilecek bir yöntem olarak da görülen bir araştırma türü olarak (Kuzu, 2009) alanyazında özellikle eylem araştırmaları ön plana çıkmakla birlikte (Babkie ve Provost, 2004, Cochran-Smith ve Lytle, 1990, 1998, 1999) bu çalışmada ele alınan araştırmacı öğretmen yaklaşımı eylem araştırmaları ile sınırlı olmayıp öğretmenlerin genel araştırma yapma bilgi, beceri ve tutumlarının tümünü kapsamaktadır. Öte yandan, eylem araştırmalarının felsefi dayanağı ile paralel biçimde, bu araştırma öğretmenlerin eğitim uygulamalarının niteliğini geliştirmek için bilimsel araştırma yapabilecekleri ve bu süreçlere aktif olarak katılabilecekleri önermesine dayanmaktadır. Öğretmenler, eğitim öğretim uygulamalarını dışarıdan bir gözle inceleyen kişilere göre öğrencileri ve sınıfları ile ilgili daha fazla bilgiye sahip olduklarından planlı ve sistematik bir sorgulama ile okul ya da sinıf ortamlarıla ilgili durumları daha iyi anlayabilir ve niteliklerinin iyileştirilmesine önemli düzeyde katkıda bulunabilirler. $\mathrm{Bu}$ yaklaşım, üniversite tabanlı üretilen ve akademik bilgiyi öncelikli kılan yaklaşıma alternatif olarak öğretmenleri güçlendirmekte ve araştırma kültürünün demokratikleştirilerek okullarda yaygınlaştırılmasına katkı sağlamaktadır (Cochran-Smith ve Lytle, 1999; Kuzu, 2009; May, 1993; Postholm, 2009).

Yukarıdaki tartışmalar ışığında araştırmacı öğretmen özelliğini teşvik etmek ve öğretmenler tarafindan sistematik bir yapıda gerçekleştirilecek araştırmaları desteklemek için (Cochran-Smith ve Lytle, 1990), bu araştırma TÜBİTAK tarafından desteklenen ve Türkiye'deki çeşitli üniversitelerin eğitim fakültelerinde lisansüstü öğrenci olarak öğrenim gören öğretmenlerin bilimsel araştırma bilgi, beceri ve tutumlarının geliştirilmesini amaçlayan bir projeden elde edilen verilere dayalı olarak gerçekleştirilmiştir. Araştırmanın amac1, katılımcı öğretmenlerin bakış açısıyla bu projenin eğitim alanında araştırma yapmak için gerekli temel nitelikleri ne düzeyde geliştirdiğini incelemektir. Bu amaç doğrultusunda çalışmaya aşağıdaki araştırma sorusu yön vermiş̧ir:

Öğretmenlerin bilimsel araştırma yeterliklerinin geliştirilmesi amacıyla yürütülen projenin, katılımcıların bakış açılarına dayalı olarak kazandırdığı temel bilgi, beceri ve tutumlar nelerdir?

\section{Yöntem}

\section{Araştırmanın Deseni}

$\mathrm{Bu}$ araştırma, ele aldığı araştırmacı ögretmen olgusunu derinlik odaklı incelemeyi amaçladığı ve bu güncel olguyu içinde yer aldığı gerçek bağlam veya içerik çerçevesinde ortaya koyduğu için nitel araştırma desenlerinden durum çalışması olarak tasarlanmıştır (Yin, 2014). Nitel durum çalışmalarının en önemli özelliği 
bir durumun derinlik odaklı araştırılarak o duruma ilişkin sonuçların ortaya koyulmasıdır (Yıldırım ve Şimşek, 2018). Bu çerçevede, TÜBİTAK tarafından desteklenen ve Türkiye'deki çeşitli üniversitelerin eğitim fakültelerinde lisansüstü öğrenimlerine devam eden öğretmenlerin bilimsel araştırma bilgi, beceri, tutumlarının geliştirilmesini amaçlayan bir proje bağlamında, projenin eğitim alanında araştırma yapmak için gerekli temel nitelikleri ne düzeyde geliştirdiği incelenmiştir.

$\mathrm{Bu}$ araştırmada incelenen proje, TÜBITTAK tarafindan belirlenen bir süre çerçevesinde yoğunlaştırılmış bir program ile beş gün içerisinde gerçekleştirilmiştir. Katılımcıların bilimsel araştırma bilgi, beceri ve tutumlarının geliştirilmesi hedefine yönelik olarak proje kapsamında tasarlanan içerik şu konulardan oluşmuştur: bilimsel araştırmanın doğası, bilimsel araştırma probleminin tanımlanması ve değişkenlerin belirlenmesi, alanyazın taramasının gerçekleştirilmesi, nicel ve nitel araştırma desenleri ile örnekleme yöntemleri, bilimsel araştırmalarda etik, veri toplama, nicel ve nitel araştırmalarda veri analizi, SPSS ve MAXQDA veri analizi programlarının kullanımı, bilimsel araştırma proje önerisi ve raporu yazma, örnek bir Avrupa Birliği projesi inceleme, örnek bir TÜBİTAK projesi inceleme ve proje önerisi yazımında karşılaşılan güçlüklerin paylaşımı ile çözüm önerileri. Projenin gerçekleştirilmesinde her biri ilgili eğitim başlıklarında uzman olan toplam 9 öğretim üyesi (3 profesör ve 6 Dr. Öğretim Üyesi) yer almıştır. Öğretim üyelerinin (eğitmenlerin) seçimi, TÜBİTAK tarafından özgeçmişlerinin ve uzmanlık alanlarının proje çerçevesinde değerlendirilmesi ile teyit edilmiştir.

\section{Katılımelar}

$\mathrm{Bu}$ araştırmanın örneklemini amaçlı örnekleme yöntemleriyle seçilen (Patton, 1990) ve araştırmanın gerçekleştirildiği projeye katılan 27 öğretmen oluşturmuştur. Katılımcıların seçiminde nitel araştırmanın özelliğine uygun olarak amaçlı örnekleme yöntemlerinden ölçüt örnekleme ve maksimum çeşitlilik örneklemesi (Patton, 1990) kullanılmıştır. İlk olarak ölçüt örnekleme yöntemi yoluyla, katılımcılar eğitim fakültesi mezunu olan ve bilimsel araştırma altyapısı bakımından desteklenmesi önem taşıyan, Türkiye'de 2006 yılı veya sonrasında kurulmuş çeşitli devlet üniversitelerinin eğitim fakültelerinde lisansüstü öğrenimlerine devam eden bireylerden seçilmiştir. İkinci olarak ise, araştırma sorusu ile ilişkili olabilecek değişkenler bakımından çeşitlilik gösteren katılımcılar arasında farklı veya ortak durumlar olup olmadığını belirlemek ve bu sayede ele alınan problemin farklı boyutlarını ortaya koymak için maksimum çeşitlilik örneklemesi yöntemi kullanılmıştır (Patton, 1990; Yıldırım ve Şimşek, 2018). Bu açıdan, katılımcıların yüksek lisans veya doktora öğrencisi olmaları, öğrenim gördükleri lisansüstü eğitim programı ve ayrıca farklı üniversitelerde öğrenim görüyor olmaları bakımından bir çeşitlilik göstermeleri sağlanmıştır.

Katılımcıların 8'i erkek (\% 29.63) 19'u kadındır (\% 70.37). Katılımcıların yaş aralığı 23 ila 40 arasında değişmektedir. 17 katılımcı yüksek lisans öğrencisi (\% 62.96), 10 katılımcı ise doktora öğrencisidir (\% 37.04). 12 üniversiteden seçilen katılımcıların öğrenim görmekte oldukları lisansüstü eğitim programları İngilizce Öğretmenliği $(n=1)$, Sosyal Bilgiler Öğretmenliği $(n=3)$, Fen Bilgisi Öğretmenliği $(n=6)$, Eğitim Programları ve Öğretim $(n=3)$, Sinıf Öğretmenliği $(n=10)$, Türkçe Öğretmenliği $(n=2)$, İlköğretim Matematik Öğretmenliği $(n=1)$ ve Psikolojik Danışmanlık ve Rehberlik $(n=1)$ programlarıdır.

\section{Veri Toplama Aracı}

Veri toplama amacıyla araştırmacılar tarafından demografik ve açık uçlu sorular ile bu soruların sondalarından oluşan yarı yapılandırılmış bir görüşme formu geliş̧irilmiştir. Demografik kısım kapsamında katılımcılara 7 soru yöneltilmiş (örn. cinsiyet, yaş, ögrenim görülen program türü ve aşama - yüksek lisans/doktora, ders dönemi/tez dönemi vb.), incelenen araştırma sorusuna odaklanan ikinci kısımda ise 6 açık uçlu soru ile sondaları yer almıştır (örn. Eğitim boyunca bilimsel araştırma yapabilme konusunda, bilgi ve beceri açısından neler kazandığınızı düşünüyorsunuz?, Bu eğitimin bilimsel araştırmalar yapma konusundaki tutumunuza ne tür katkıları oldu?). Görüşme formunun taslağındaki soruların anlaşılırlığı ve araştırmanın amacına uygunluğu konusunda program geliştirme alanındaki üç farklı uzmandan görüş alınmıştır. Uzman görüşleri ışığında bazı soru ve sonda eklemeleri yapma (örn. Eğitim kapsamında neler yaptınız? Derslerin işlenişi ne tür etkinlikler yoluyla gerçekleştirildi?), sorular arasındaki sıralamayı tekrar gözden geçirme gibi gerekli düzenlemeler yapıldıktan sonra görüşme formunun geçerlik ve güvenirliğini sağlamak amacıyla araştırmanın katılımcıları dışında olup eğitim fakültesi mezunu ve lisansüstü öğrenimine devam eden iki kişi ile bireysel ve başka iki kişi ile de grup görüşmesi yoluyla pilot çalışmalar yapılmış, görüşmenin süresi ile soruların akışı, anlaşılırlığı ve araştırmanın amacı açısından uygunluğu veri toplama sürecinden önce test edilmiştir (Kvale, 2007; Marshall ve Rossman, 2011; Maxwell, 2013). Pilot çalışma sonrasında görüşme formunda herhangi bir değişiklik ihtiyacı oluşmamıştır.

\section{Veri Toplama Süreci}

Veri toplama aracının geliştirilmesini takiben, verilerin toplanması araştırmacılar tarafindan yüz yüze gerçekleştirilen ve her biri 6-7 katılımcıdan oluşan 5 odak grup görüşmesi ile gerçekleştirilmiştir. Odak grup görüşmeleri, bireysel görüşmelere kıyasla daha rahatlatıcı nitelikte olabilecek 4 ila 12 kişi arasında değişen bir grup ortamında gerçekleştirilmeleri ve gruptaki bireyler arasında bir etkileşime olanak sağlayarak görüşme 
sorularına verilen yanıtların kapsamı ve derinliği bakımından zengin bir veri seti oluşturmaya yardımcı olmaları açısından önem taşımaktadır (Marshall ve Rossman, 2011). Belirlenen odak gruplar, katılımcıların yüksek lisans veya doktora öğrencisi olması, lisansüstü öğrenim gördükleri üniversite ve lisansüstü eğitim programları gibi özellikleri bakımından benzer dağılıma sahip olacak şekilde oluşturulmuştur. Odak grup görüşmeleri, araştırmacılar tarafindan proje bitiminde gerçekleştirilmiştir. Araştırmaya katılım için gönüllülük ilkesi esas alınmış, yapılan tüm odak grup görüşmeleri katılımcılardan alınan izinler doğrultusunda verilerin zengin nitelikte olması, veri kaybı olmaması, görüşmenin daha akıcı ve derinlik odaklı ilerlemesi ve görüşmecinin katılımcıları daha dikkatli dinleyebilmesi amacıyla (Patton, 1990) ses kayıt cihazı ile kaydedilmiştir. Odak grup görüşmeleri yaklaşık 55 ila 65 dakika arasında tamamlanmıştır.

\section{Veri Analizi}

Görüşmelerin çözümlenmesini takiben, verilerin analizi araştırmacılar tarafından NVivo 10 nitel veri analizi programı kullanılarak içerik analizi yöntemi (Patton, 1990) ile gerçekleştirilmiştir. Bu bağlamda, veriler öncelikle belirli sözcük, sözcük öbeği veya paragraflara uygun kodlar verilerek daha küçük birimlere ayrılmış (Creswell, 2013; Miles ve Huberman, 1994), sonra ise bu kodlar arasında çeşitli ilişkiler, bağlantılar ve yapılar oluşturularak verileri temsil eden daha geniş temalar veya kategoriler elde edilmiş̧ir (Bogdan ve Biklen, 2007). Kodlayıcılar arası uyumun sağlanması için iki uzmandan belirli sayıda görüşme metnini kodlamaları istenmiş, böylece elde edilen kod ve kategoriler arasındaki uyum incelenmiştir (Marshall ve Rossman, 2011; Miles ve Huberman, 1994; Patton, 1990). Bulguların sunumunda katılımcıların kimlikleri gizli tutularak katılımcıların temsilinde sayılar kullanılmıştır (örn. K1: Katılımc1 1).

\section{Geçerlik ve Güvenirlik}

Araştırmanın geçerlik ve güvenirliğinin inandırıcılık, aktarılabilirlik, tutarlık ve teyit edilebilirlik açısından sağlanması için çeşitli yöntemler kullanılmıştır. İnandırıcıllğın sağlanması için uzman incelemesi, pilot çalışma, uzun süreli etkileşim, farklı kodlayıcılar arasında önce bağımsız kodlamaların yapılması ve sonra bir araya gelerek ortak tartışmalar yoluyla uyumun sağlanması gibi çeşitli yöntemlere başvurulmuştur. Aktarılabilirlik için uygun amaçlı örnekleme yöntemleri ve araştırmanın gerçekleştirildiği bağlam, katılımcıların özellikleri, veri toplama, veri analizi ve bulguların raporlanması gibi süreçler için ayrıntılı betimleme yöntemi kullanılmıştır. Son olarak tutarlık incelemesi yönteminden yararlanılarak veri toplama araçlarının oluşturulması ve veri analizi aşamalarında bir uzmanın görüşüne başvurulmuş, teyit incelemesi yöntemi kullanılarak ise veriler ışığında ulaşılan yargıların tutarlığının aynı uzman tarafından incelenmesi sağlanmıştır.

\section{Bulgular}

Odak grup görüşmeleri sonucunda elde edilen bulgular araştırma sorusu çerçevesinde bilimsel araştırma bilgisi, bilimsel araştırma becerileri ve bilimsel araştırma yapmaya yönelik tutum-inanç olmak üzere üç tema altında ve katılımcıların ifadeleriyle birlikte aşağıda sunulmuştur.

\section{Bilimsel Araştırma Bilgisi}

Katılımcıların çoğu bilimsel bir araştırma sürecinin aşamaları konusunda bu projenin bilgi düzeylerine önemli bir katkısı olduğunu ifade etmiş ve bu aşamaları özellikle sistematik ve bütüncül bir yaklaşımla ilişkilendirebilmelerinin önemini vurgulamıştır. Örneğin, doktora düzeyindeki katılımcılardan biri bu konudaki görüşlerini aşağıdaki gibi açıklamıştır:

...Bilimsel araştırmanın çatısının zihnimde oturduğunu düşünüyorum. ...Ben araştırmamı nitel desenle yapmayı düşünüyordum ama nitelde okuldayken öğrendiğimiz şeylerde hep bir eksikliğim vardı açıkças1. Desenlerden tutun da örneklemi nasıl seçeceğim, desende neye karar vereceğim, o ilerleyiş nasıl olacak, süreç nasıl ilerleyecek bunlarla ilgili hep sıkıntı vard1 (K1).

Yüksek lisans derslerini tamamlamış ve tez aşamasına geçmiş olan katılımcılardan biri ise görüşlerini şu şekilde özetlemiştir:

...Şu anlamda çok güzel bir işleyiş vardı. Bu proje bize bilimsel araştırma yapmanın iskeletini sundu, bu açıdan çok faydalı oldu. ... İçerik ve bağlantılar çok başarılıydı, baştan sona konuları bir arada görebildiğim ve eğitmenler püf noktaların/konular arasındaki ilişkilerin altını çizdiği için bilimsel araştırmanın bütünü hakkında bir fikir ve bilgi sahibi oldum. Lisansüstü eğitimimde bu bağlantılar kopuktu (K9).

Katılımcılar bilimsel araştırma sürecine ilişkin öncelikle bilimsel araştırmanın doğası ve temelleri konusunda bilgi edindiklerini belirtmişlerdir. Örneğin, katılımcılardan biri (K21) projenin kendisine bu konuda kazandırdığı bilgileri “...Bilimin doğasıyla başladık, bilme yollarını inceledik. Evren, örneklem, nitel araştırma, nicel araştırma vb. tanımların özelliklerini tartıştık. Nitel ve nicel paradigmalar arasındaki genel farklılıkları öğrendik." şeklinde açıklamıştır. 
Birçok katılımcı bilgi edindikleri başka bir boyut olarak bilimsel araştırmalarda problem durumunun öneminden bahsetmiştir. Örneğin, bir katılımc1 (K22) bu konuda “...Y Yani bir araştırma problemini ortaya koyarken nelere dikkat etmeliyiz, her soru araştırma problemi olur mu, iyi bir araştırma sorusunun özellikleri nelerdir bunları tartışarak öğrendik.” diyerek görüş bildirmiştir.

Katılımcıların tamamı bilimsel araştırma yapma konusunda proje boyunca bilgi edindikleri en önemli boyutun bilimsel araştırmalarda etik konusu olduğunu vurgulamıştır. Aşağıda bir katılımcının bu konudaki ifadelerine yer verilmiştir:
...Etik konusu gerçekten dikkatle dinlediğim konulardan biri oldu. Bu konuyu ne lisansta ne de yüksek lisansta bilimsel araştırma yöntemleri dersinde işlemedik. Günlük hayatta biliyordum ama akademik olarak bilmiyordum. Örneğin, alıntı yaparken dikkat edilecek kurallar... İhlâller nelerdir, bunların cezaları nelerdir... Eğer bir araștırmada bazı etik kurallar ihlâl ediliyorsa bu durum araștırmanın amacına hizmet etmiyor ve bunu araştırmanın ruhunu yıkan bir şey olarak görüyorum. ...Bu eğitime katıldıktan sonra dönüp yüksek lisans tezimde yaptığım yanlışları düzeltmek istedim ama düzeltme şansım yok ne yazık ki (K26).

Birçok katılımcı araştırma desenleri konusunda yaşadıkları güçlüklere işaret ederek katıldıkları bu proje kapsamında araştırma desenleri ile ilgili edindikleri bilgilerin kendileri için önemli ölçüde yol gösterici olduğunu ifade etmiştir. Örneğin, K16, bu konuda "Nicel araştırma olsun, nitel araştırma olsun. Araştırma desenini belirlemekte çok zorlanıyoruz. Birbirinden kesin hatlarla ayrılmayan çok fazla şey var. Onlar daha da netleşti, nasıl bir yol izleyeceğimi artık biliyorum." şeklinde görüş belirtmiştir. Başka bir katılımcı da nicel araştırmalara kıyasla bu kapsamda özellikle nitel araştırmalara değinerek araştırma desenleri ile ilgili kazanımlarından bahsetmiştir:

...Türkiye'de eğitim alanında nicel araştırma daha çok yapıldığı için nitel araştırmayı çok fazla bilmiyoruz. Projedeki nitel araştırma dersinde nitel araştırmanın doğası ile başladık. Nasıl yapıldığını, araştırma desenleri arasındaki ayırımı öğrendik. Uygulamadan önce kuramsal temelini anlamak çok önemli (K7)

Katılımcıların önemli bir kısmı literatür taraması konusunda sahip oldukları bilgileri bu proje yoluyla gözden geçirme firsatı elde ettiklerini söylemiştir. Çoğu katılımcı literatür taraması çerçevesinde daha önceden bilmediği veri tabanları, anahtar kelimelerin kodlanması, arama motorlarının kullanımı vb. çeşitli boyutlarda yeni bilgiler edindiğinden bahsetmiştir. Literatür taraması konusunda edindikleri bilgilerden bahsederken birçok katılımcı özellikle uluslararası kaynaklara değinmiş ve bu konuda önemli eksikleri olduğunu fark ettiğini dile getirmiştir. Bir katılımcı lisansüstü öğreniminde aldığı bilimsel araştırma yöntemleri dersi ile kıyaslamada bulunarak bu projenin literatür taraması konusundaki bilgisine katkısından ve diğer katılımeı ise uluslararası kaynaklar konusundaki kazanımından şu şekilde açıklamıştır:

Bu eğitim sonunda bir dönem boyunca gördüğüm araştırma dersinin yetersiz kaldığını anladım. Süre kısıtlı olmasına rağmen burada daha iyi bir eğitim aldığımı düşünüyorum... Literatür taramada ne kadar eksik olduğumu, bilmediğimiz ne kadar çok kaynak olduğunu ve aslında bunların yalnızca onda birini kullandığımızı, önümüzde derya deniz varsa bizim bir damla suyla yetindiğimizi fark ettim. Örneğin, veri tabanlarının çeşitliliği, anahtar kelimelerin doğru kodlanması ve arama motorlarında aranma biçimi öğrendiğim şeylerden bazıları... (K4).

Literatür taramasında eksiklerim olduğunu fark ettim. Sadece Türkiye'deki makaleleri bulmaya çalışıyordum ve hatta onu da belirli sitelerden yapıyordum. Şimdi daha fazla açılmak gerektiğini öğrendim. Aslında literatür taramak nedir, bir araştırmacı literature neden hakim olmalıdır buradan başlıyor mesele (K2).

Yukarıda sunulan bulgulara ek olarak katılımcıların önemli bir kısmı nicel ve nitel araştırmalarda örnekleme yöntemleri, veri toplama, veri analizi ve bulguları raporlama gibi çeşitli açılardan projenin kendilerini araştırmacı olarak geliştirdiğini ifade etmiştir. Veri analizi konusunda katılımcılar hem kuramsal bir altyapı kazandıklarını hem de farklı veri analizi programları tanıyarak özellikle sonuçları yorumlama bakımından önemli ölçüde bilgi edindiklerini vurgulamışlardır. Örneğin, katılımcılardan biri nicel veri analizi programı olarak SPSS konusunda, diğeri ise nitel veri analizi programı olarak MAXQDA'ya ilişkin edindiği bilgiden şu şekilde bahsetmiştir:

Aslında SPSS'i daha önce kaç defa gördük. Ama mesela etki büyüklüğü değerinin nereden kontrol edileceğini bilmiyordum. Benzer şekilde, Levene testine bakıyorduk, değerin .05'ten büyük çıkmasını bekliyoruz ama konu anlatımı sırasında ezberlemiştim ben mantığını çok da anlayamadan. Aklımda pek çok eksik nokta olduğunu, buraya aslında yarım yamalak geldiğimizi bu eğitimde fark ettim, bunlar burada yerine oturmuş oldu (K27).

NVIVO programı ile bir hocamla çalışma yapıyorum. Farklı olarak burada MAXQDA'yı ilk kez duydum ve onu da ögrrenmem şu anda benim için büyük bir artı oldu, ikisi arasında kıyaslama yapabileceğim. Benziyorlar ama MAXQDA'nın birçok farklı özelliğini de öğrenmiş oldum. Mesela MAXQDA'da grafiklerin daha renkli kullanılabileceğini gördüm. ...Ya da kadın ile erkeği otomatik olarak ayırıyormuş, aslında kolay yolu varmış yani. Biz biraz fazla manuel çalışmaya alışmışız sanırım. Veri analizi ile ilgili süreçte eksiklerimi tamamlama yönünde bir firsat oldu bu eğitim benim için (K25). 
Bulguların raporlanması konusunda ise katılımcıların özellikle uluslararası standartlara değindikleri görülmüş ve bu açıdan bazı katılımcılar görüşlerini aşă̆ıdaki gibi açıklamıştır:

...SPSS'i bize hocalarımız anlattı bu tür derslerde ama onun nasıl yorumlanması gerektiğini ve dahası nasıl raporlanması gerektiğini bu kadar detaylı anlatmamışlardı. Uluslararası istatiksel terminolojiye göre ifadelendirerek raporlamayı ilk defa burada düzgün bir şekilde gördüm ve öncesinde eksik geldiğimi fark ettim (K8).

Benim bu eğitimde kazandığım en önemli şeylerden biri raporlamada uluslararası standartları öğrenmek oldu. Raporlamayı ve bulguları yazmayı belli ölçüde biliyordum ama uluslararası standartlar açısından eksik yapıyormuşum bunu fark ettim. Örneğin, tabloları farklı sunuyordum ben, bu șekilde detayl yönlendirilmemiştik. Benzer şekilde, etki büyüklüğünü raporlamak hiç kullanmadığımız bir şeydi, çok iyi bir nokta oldu bu benim için (K9).

Katılımcıların önemli bir kısmı farklı proje türleri konusunda bilgilendiğinden bahsetmiştir. Birçok katılımcı bu kapsamda ayrıca proje önerisi yazma konusunda kendisini geliştirme olanağı elde ettiğini dile getirmiştir. Örneğin, iki katılımcı bu boyutlara ilişkin kazanımlarını şu şekilde ifade etmiş̧ir:

...Yani şöyle, evet her zaman bir projeden bahsediliyor ama bir projenin kapsamı içerisinde neler yer aldığını ben burada gördüm. Bir şeyin sadece varlığından bahsedip içeriğinden bahsedilmezse o bize sadece boş bir çerçeve olarak kalıyor. Proje nedir sorusunun yanıtı benim açımdan burada somutlaşmış oldu, eğitimden sonra kendimin de yapabileceği fikri oluştu bende (K15).

TÜBİTAK projesi, Avrupa Birliği (AB) Projesi ve BAP (Bilimsel Araştırma Projesi)... Örneğin, ben BAP'1 hiç bilmiyordum, hatta burada merak edip baktım bizim üniversitede var mı diye, meğer varmış... Aynı şekilde $\mathrm{AB}$ projelerinin kapsamının çok daha geniş olduğunu, uluslararası alanda öncelikli ve yenilikçi konularda ve birden fazla partnerle yapıldığını öğrendim. Proje türleri açısından bize bu eğitimin büyük bir katkısı olduğunu söyleyebilirim (K21)

Yukarıda sunulanlara ek olarak birçok katılımeı proje süresince bilimsel araştırmanın çeşitli aşamalarına ilişskin temel akademik kaynaklar açısından zengin bir bilgi edinmiş olmalarının da önemli bir kazanım olduğunun altını çizmiştir. Bu açıdan, katılımcıların çoğu aynı zamanda akademik ağlarını zenginleştirmek için de önerilen kaynaklar yoluyla bir repertuvar geliştirdiklerini belirtmiştir. Bilimsel Araştırma Bilgisi temasının kapsadığ kodlar Tablo 1'de sunulmaktadır:

Tablo 1

Bilimsel Araştırma Bilgisi Teması ve Kapsadı̆̆ Kodlar

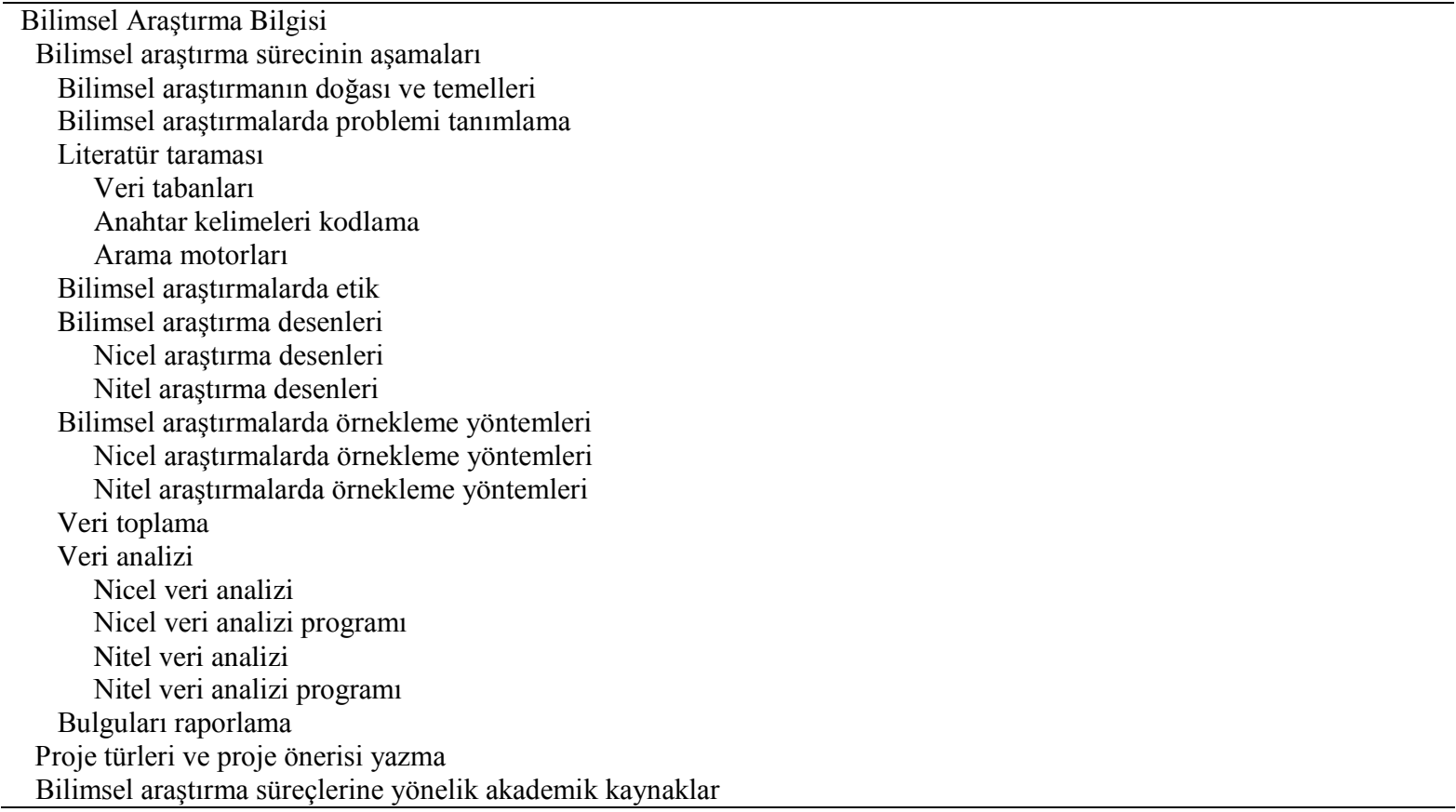

\section{Bilimsel Araştırma Becerileri}

Katılımcılardan bazıları proje boyunca bilimsel araştırma sürecinin aşamalarına yönelik özellikle planlama becerisi geliştirdiklerinden bahsetmiş̧tir. Örneğin, bir katılımcı bu konuda aşağıdaki açıklamada bulunarak bilimsel araştırma yürütme sürecinde planlamanın önemine dikkat çekmiştir: 
Araştırmayı en baştan sistemli bir şekilde planlamanın gerekliliği konusunda açıkçası kendime çokça ders çıkardım. Eğitim boyunca öğrendiğ́imiz sistematik aşamalara ek olarak son derslerimizde yaptığımız gibi örnek bir araştırma planlamak da bu konuda beni geliştirdi diyebilirim (K20).

Katılımcıların önemli bir kısmı planlama becerisi ile ilişkili olarak proje boyunca en önemli kazanımlarından birisinin araştırma/proje önerisi yazma becerisi geliştirmek olduğundan bahsetmiştir. Bu açıdan, birçok katılımcı proje boyunca çeşitli derslerde katıldıkları uygulamalı etkinliklerin ve grup çalışmalarının destekleyici rolünden bahsetmiştir. Bazı katılımcılar oturma düzeninin de etkisi olduğundan bahsederek önerilerde bulunmuştur. Örneğin, bir katılımcının bu konudaki görüşleri aşağıdaki gibidir:

Proje türlerini öğrenmemize ek olarak bir araştırma önerisi geliştirmeye çalışmak ve uygulamalı olarak tartışmak yararlı oldu. Bu benim gözümde büyüyen bir şeydi, grup çalışması yapıp bir öneri üretmeye çalıştık ve taslak üzerinde uygulama yapmış olduk. Araştırma sorusundan yöntemine kadar planlamaya çalışmak yararlı oldu, bu sonrasında ortaya güzel bir şey çıkmasını sağlıyor. Ama sınıf düzeni U düzeni veya küçük kümeler şeklinde olabilirdi bu derslerde (K13).

Birçok katılımcı proje boyunca araştırma önerisi hazırlama sürecinin kendileri için özellikle eleştirel ve yaratıcı düşünme becerilerinin geliştirilmesi açısından büyük bir katkısı olduğunu ifade etmiştir. Bu açıdan da, katılımcıların önemli bir kısmı derslerin aktif öğrenme yöntemleri ile işlenerek öğrenci motivasyonunu ve ilgisini artırmış olmasının, uygulamalı etkinliklerin ve eğitmenlerin yetkinliklerinin önemini vurgulamışlardır. Bazı katılımcılar özellikle yapılan araştırmaların niteliği konusunda eleştiriler geliştirmiş ve bu açıdan akademik teşvik uygulamasının olumsuz etkisine değinmiştir. Katılımcılardan bazıları görüşlerini şu şekilde açıklamıştır:

Projede aldığımız eğitim bir ufuk açtı önümüzde. Belki de içinde olduğumuz kalıptan çıkardı bizi, yani farklı şeyler düşünmemizi sağladı. Örneğin, proje çalışmalarında yaptığımız grup çalışmalarında ciddi bir beyin jimnastiği yaptık ve arkadaşlarla o tartışmalar sırasında çok güzel fikirler ortaya çıktı. ...Ben bunu projenin ders içeriklerine, yaptığımız etkinliklere ve hocaların alanlarında çok yetkin kişiler olmalarına da bağlıyorum (K26).

Olabildiğince alanında uzman kişilerden eğitim almak için bu projeye katılmıştım, gerçekten de eğitim sonlandığında başta hedeflediğim şeye ulaştığımı söyleyebilirim. Odaklanıp daha temiz bir şekilde, çalakalem olmadan, daha sistematik, eleştirel, daha sorgulayıcı ve profesyonel bir şekilde nitelikli çalışmalar yapmaya odaklanacağımı söyleyebilirim. ...Akademik teşvik vb. durumlardan dolayı niteliksel bakılmıyor genelde... Kendi hocalarımız da bu şekilde yönlendirmemişti, içeriğe bakılmıyordu yani açıkçası pek... (K3).

Katılımcıların tümü proje süresince geliştirdikleri becerilerden birinin veri analizi olduğunu vurgulamıştır. Bu bakımdan, birçok katılımcı biri nicel ve biri nitel veri analizi programı olmak üzere proje süresince farklı programlarla uygulamaya dayalı bir eğitim almalarının rolünün altını çizmiştir. Bazı katılımcılar daha önceden bu programları bildiklerini ancak programlarla ilgili çeşitli özellikleri proje kapsamında öğrendiklerini belirterek proje sonrasında veri analizi programlarını daha etkili kullanabilecek yönde bir beceri geliştirdiklerini ifade etmişlerdir. Bazı katılımcılar ise özellikle nitel araştırmalarda teknoloji destekli veri analizi programı kullanımına dayalı daha önceden herhangi bir eğitim almadıklarını vurgulamışlardır. Bu çerçevede, bazı katılımcıların ifadeleri aşağıda yer almaktadır:

\footnotetext{
...SPSS ile ilgili birçok kitap alıyoruz ama bir analiz yapacağımız zaman karıştırıyoruz. O yüzden önce teorik kısımda analizlerin mantığını anlamamız iyi oldu. ...Belki her zaman yaptığım analizlerdi ama SPSS'te uygulama yapınca hiç dikkat etmediğim noktaları yakaladım. Normalde kullanmadığım hatta hiç bilmediğim bazı özellikleri ve püf noktaları öğrenmiş oldum, bu anlamda çok büyük bir kazanım oldu diyorum kendi adıma (K15).

Nitel veri analizinde program kullanıldığını burada duymuş oldum ilk kez. Aslında kendi alanımda daha çok nitel araştırmalar yapılmasına rağmen MAXQDA'yı burada öğrendim, başka arkadaşlar NVIVO kullanıyorlarmış onu da duymamıştım. MAXQDA'yı kullanarak ses, doküman vb. farklı verilerin nasıl analiz edilebileceğini görmek ve programın değişik özelliklerini öğrenmek yararlı oldu benim için (K4).
}

Son olarak birçok katılımcı öz değerlendirme, iletişim ve grupla çalışma becerilerinin geliştirilmesi konusunda da projenin kendilerine önemli bir katkısı olduğundan bahsederek bu sayede proje kapsamında çeşitli üniversitelerden ve disiplinlerden olmak üzere hem kendi aralarında hem de eğitmenler ile yeni akademik bağlantılar geliştirebildiklerini ifade etmiştir. Bilimsel Araştırma Becerileri temasının kapsadığı kodlar Tablo 2'de özetlenmektedir: 
Tablo 2

Bilimsel Araştırma Becerileri Teması ve Kapsadı̆̆ Kodlar

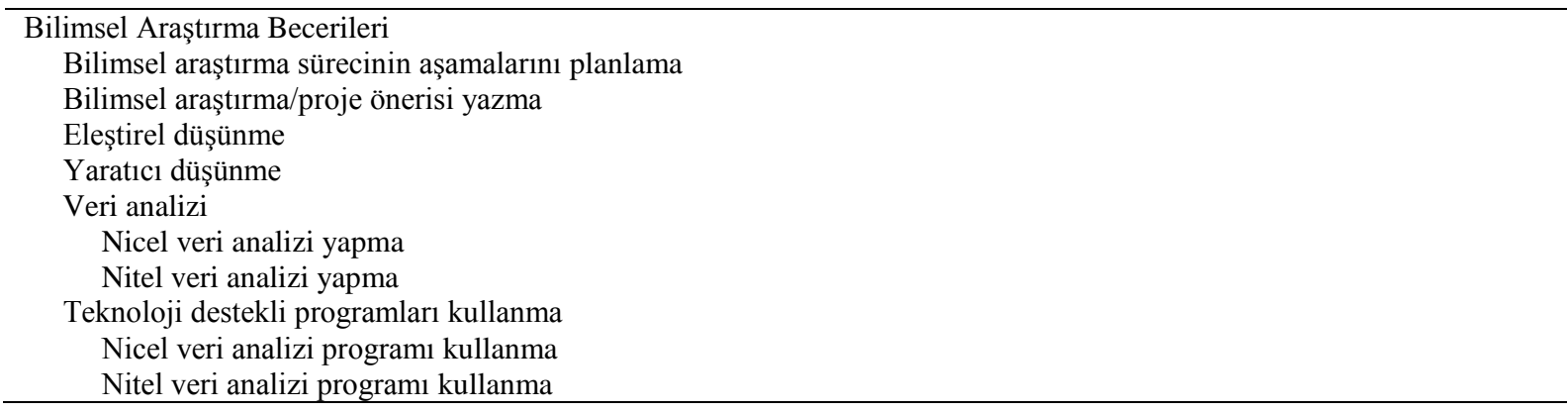

\title{
Bilimsel Araştırma Yapmaya Yönelik Tutum-İnanç
}

Katılımcıların büyük bir kısmı katıldıkları bu projede aldıkları eğitimin en temelde bilimsel araştırma yapmaya yönelik genel tutumlarını olumlu yönde etkilediğini belirtmiştir. Birçok katılımcı bu kapsamda özellikle sistematik, planlı ve nitelikli araştırmalar yapma yönünde bir bakış açısı geliştirdiklerinden bahsetmiştir. Bu açıdan, bazı katılımcıların görüşleri aşağıda sunulmaktadır:

\begin{abstract}
...Yani bilimsel araștırma neden yapılır? Bizde hani şöyle bir mantık vardı, işte süregelen kariyer kaygısı ve buna bağlı olarak yayın yapma sevdası... Yükselmek için yani. Yayın yapılır ama bundan ziyade bir şeyi merak edip gerçekten sistemli bir şekilde detaylandırmak önemli. Asıl amaç derinlerine inerek iyi bir şekilde yapmak, bu amaçla araştırma yapılabileceğini de görmüş olduk aslında. Bu konuda olumlu bir tutum geliştirmemi sağladı diyebilirim (K15).
\end{abstract}

Araştırma yapmayı yaşam biçimi olarak edinmek gerçekten farklı, ne kadar azimle ve geniş bir bakış açısıyla çalışmamız gerektiğini öğrendim. Ne tür şeylerden kaçınmam gerektiğini veya nasıl çalışıp nasıl çalışmamam gerektiğini öğrendim aslında, araştırma yapmaya yönelik daha farklı bir bakış açısı oluştu bu yüzden. Yapmış olmak için değil de daha niteliksel ve her aşamada bir rasyonele dayalı ilerleyeceğimi söyleyebilirim.. (K20).

Araştırma yapma konusundaki genel tutum değişikliğine ek olarak birçok katılımcı bilimsel araştırmanın doğasını sorgulamaya yönelik bir tutum ve bakış açısı geliştirdiklerini ifade etmiştir. Örneğin, bir katılımcının (K16) bu konudaki görüşü "Eğitim sürecinde her an aklımda farklı problemler belirdi. Alanımla ilgili beni sorgulatma hali çok güzeldi. Ne yapıyorum, niye yapıyorum, sürekli bu soruları sorarak ve araştırma sorusunu analiz ederek desteklendik burada." şeklinde olmuştur.

Çok sayıda katılımcı proje boyunca çeşitli açılardan öz yeterlik inançlarının da yükseldiğini ifade etmiştir. Bu konuda öne çıkan görüşlerden bazıları aşağıda yer almaktadır:

...Hani niye yapamayayım ki diyor insan yani. Bu duyguyu biraz daha geliştirmiş oldum bu proje boyunca. Mesela hep bir projeden bahsediliyor, hep soyut kalıyordu ve genelde bizim harcımız değil girmeyelim diye düşünürdük ama şu an oturdu. Evet, ben de proje yapabilirim diyebiliyorum artık en azından (K13).

...Aslında bu eğitim ile cesaretlendim, iyi bir motivasyon kaynağı oldu bana. Birçok şey öğrendik ama onun dışında bir şeyleri yapabileceğimize inandırdı. Ben açıkçası bir araştırma sürecinde tedirginlik duyuyordum, o tedirginlik gitti üzerimden (K26).

Öz yeterlik inançlarındaki değişim ile paralel olarak birçok katılımcı bilimsel araştırma yapma sürecinin belirli aşamalarına yönelik olumlu tutum geliştirdiklerini söylemiştir. Örneğin, bir katılımcı (K9) proje önerisi yazma konusunda "Lisansta da lisansüstünde de projelerde bulunmadım ben hiç. Şimdi ilgim artt1, döndüğüm zaman hocalarıma birlikte bir proje yazmak istediğimi söyleyeceğim." diyerek görüşlerini açılamıştır. Bir başka katılımcı da proje önerisi yazmaya yönelik olumlu yöndeki tutum değişikliğinden şu şekilde bahsetmiştir:

Proje oluşturmak benim gözümde büyüyen bir şeydi, proje yapan arkadaşlarımdan olumsuz etkilenmiştim. Proje yazmak ve yürütmenin yapılabilir olduğunu düşünmeye başladım, gözümü korkutacak bir şey değilmiş, birkaç arkadaş bir araya gelerek ve işbirliği yaparak projeler üretebiliriz (K27).

Katılımcıların tamamının proje boyunca olumlu tutum geliştirdiklerini ifade ettiği boyutlardan biri de bilimsel araştırmalarda etiktir. Birkaç katılımcı bu konuda araştırma etiği, yazarlık etiği ve akademik dürüstlük boyutlarındaki görüşlerini aşağıdaki gibi açıklamıştır:

Ben en çok etik dersinden etkilendim. Etik bir araştırmacı anlayışını tartışmak benim de kendimi sorgulayıp silkelenmemi sağladı aslında. Projenin bana en büyük katkısı sanırım bu oldu, kişisel çıkarın için bilim çıkarını heba etmemelisin, etik bir araştırmacı olmalısın her aşamada. Örneğin, paralı dergide hiçbir zaman yayın yapmamam gerektiğini bu süreçten sonra çok daha iyi anladım diyebilirim, dik durabilmek çok önemli. Bizlere bu konuda önerilen kaynakları edinip yanımdan ayırmayacağım (K24). 
...Etik konusunda tartıştıklarımızın ne kadar önemli olduğunu fark ettim. Başkasının ürettiği bir şeyi bilinçsiz de olsa almak ne kadar kötü bir durummuş bunun farkındalığı oluştu. ...Ya da birden fazla yazarlı çalışmalarda sadece kendinden değil ekibindekilerin yaptıklarından da sen sorumlusun aslında, bundan çok etkilendim ve hiç unutmamam gereken bir şey (K22)

Çok sayıda katılımcı bu projenin bilimsel araştırmanın önemli bileşenlerinden biri olan veri analizi yapma konusunda olumlu tutum geliştirmelerine büyük bir katkısı olduğunu söylemiştir. Bu açıdan, birçok katılımcı özellikle veri analizi programlarına yönelik mevcut kaygılarından bahsederek proje süresince bu tür programlar ile ilgili pozitif tutum geliştirebildiklerini anlatmıştır. Örneğin, bir katılımcı, bu eğitim sayesinde bir istatistik programına yönelik kaygısının azaldığını belirtmiştir:

Kendi adıma konuşacak olursam SPSS hep gözümü çok korkutan bir şeydi. Ama tezimde karma yöntemle çalışacağım ve bu eğitimden sonra SPSS ile ilgili korkularım azaldı. Buraya gelmeden önce eğitimin içeriğinde SPSS'i görünce eyvah deyip biraz endişelenmiştim. Kaygımı yenmem bakımından iyi oldu benim için $(\mathrm{K} 1)$

Katılımcıların birçoğu teknoloji destekli veri analizi programları kullanımına yönelik tutumlarındaki değişimden bahsederken bilimsel araştırma yapma sürecinin çeşitli aşamalarında genel olarak teknoloji kullanımına yönelik olumlu bir tutum ve bakış açısı geliştirdiklerinden de söz etmiştir. Katılımcılar bu programlara işlevsellikleri ve araştırma yapma sürecinde kendilerine daha etkili bir zaman yönetimi olanağı sağlayacağını fark etmeleri bakımından ilgi duymaya başladıklarını açıklamışlardır. Katılımcılardan birinin görüşlerine aşağıda yer verilmektedir:

...Örneğin, literatür taramasında da web'de kullanabileceğim programları görmek ilgimi çekti. ...Sanırım biz genel olarak teknolojiye yakından ilgi duyan bir toplum değiliz, o yüzden birçok şeyi programlarla değil de manuel olarak yapıyoruz. Okuldaki hocalarımızdan da böyle gördük, teknoloji konusunda yatkınlıklarının yüksek olduğunu pek söyleyemem... Kendi adıma teknolojik programlarla ilgili iyi bir rehber oluştu kafamda, bir farkındalık gelişti, daha çok takip edeceğimi ve kullanacağımı düşünüyorum literatür tararken ya da ne bileyim nitel verileri analiz ederken (K14).

Katılımcıların çoğu proje süresince bilimsel araştırma yapma konusunda geliştirdikleri olumlu tutumdan bahsederken aynı zamanda araştırma sürecinin çeşitli bileşenlerine yönelik uluslararası bir bakış açısı geliştirmiş olmalarının da öneminin altını çizmiştir. Örneğin, bazı katılımcılar bu çerçevede görüşlerini şu şekilde açıklamıştır:

\begin{abstract}
...Derslere alanında uzman kişiler geldi. Aralarında eğitimini yurtdışında almış hocalarımız oldu ve bunun da yansımalarını görmüş olduk. Alanyazında sadece Türkiye'deki makaleleri takip etmektense yurtdışındaki çalışmaları da sıklıkla takip ettiklerini net bir şekilde gözlemledim. Hani bu bakış açısını kazandım, bu durumu yeni fark ettim diyelim (K4).

...Projelerin sadece Türkiye'yi ilgilendiren bir konuda değil de uluslararası öncelik taşıyan bir konuda belirlenmesi de önemli, yani ürüne evrensellik katıyor, bu çok önemli bir boyutmuş. ...AAraştırma yapmaya yönelik geniş bir vizyon kazandığımı rahatlıkla söyleyebilirim burada, bir kalıbın içindeymişim, oradan çıkardı beni ve kalıbın dışındakileri de fark etmemi sağladı (K9).
\end{abstract}

Benzer şekilde çok sayıda katılımcı proje boyunca çeşitli etkinlikler ve tartışmalar yardımıyla kendi akademik alanları dışında disiplinlerarası bir bakış açısı ve tutum geliştirebildiklerinden bahsetmiştir. Bu çerçevede, katılımcılar aynı konuya farklı açılardan bakma fırsatı elde etmenin araştırmacı olarak kendilerine önemli bir katkı sağladığını belirterek grup çalışmalarının yaygınlaştırılabileceğini önermişlerdir.

Son olarak, birçok katılımcı yukarıda bahsedilen tutum özelliklerini proje boyunca geliştirebilmelerinde eğitmenlerin alanlarındaki yetkinlikleri, bilimsel araştırma sürecine yönelik disiplinli tutumları, iletişime açık olmaları, etkili bir rehberlik sağlamaları ve yenilikleri takip etmeleri gibi yönlerden kendileri için bir rol model sergilemelerinin büyük bir etkisi olduğunu ve bu konularda da olumlu bir tutum geliştirdiklerini ifade etmişstir. Bilimsel Araştırma Yapmaya Yönelik Tutum-İnanç temasının kapsadığı kodlar Tablo 3 ’te yer almaktadır: 
Tablo 3

Bilimsel Araştırma Yapmaya Yönelik Tutum-İnanç Teması ve Kapsadiğı Kodlar

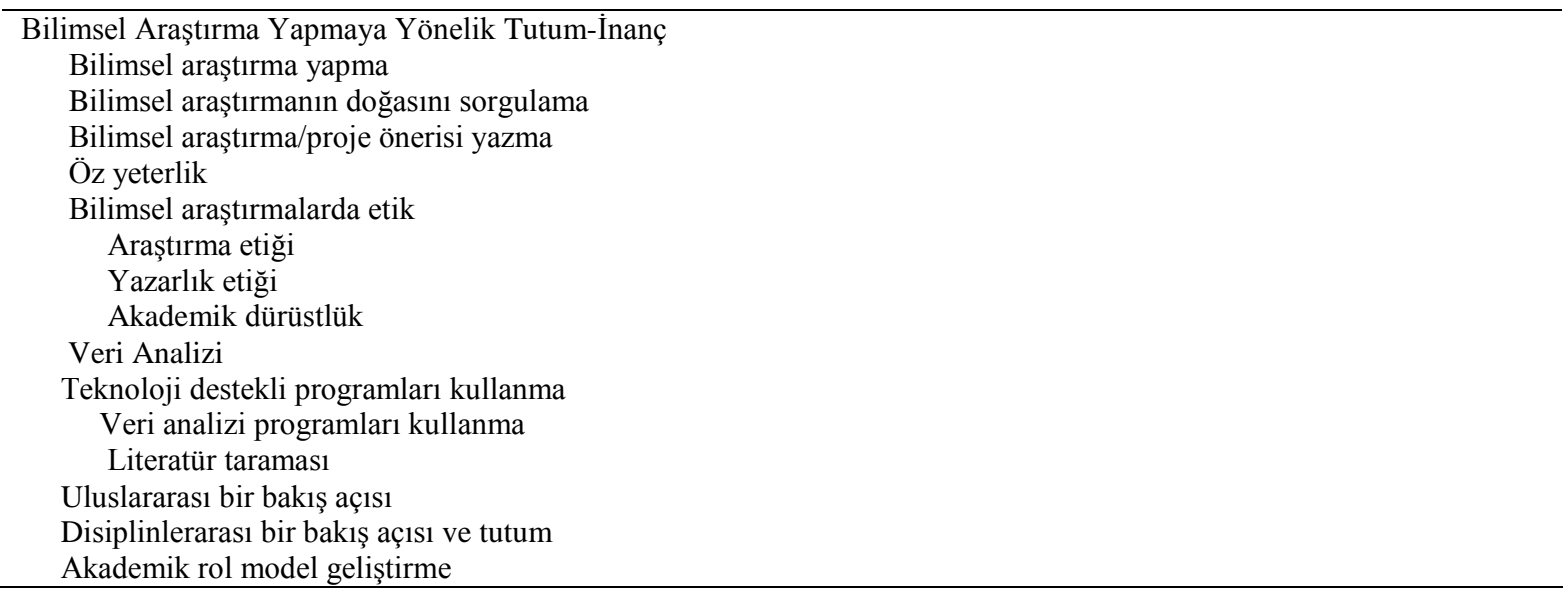

\section{Sonuç ve Tartışma}

$\mathrm{Bu}$ araştırma TÜBİTAK tarafından desteklenen ve 2006 y1lı veya sonrasında kurulmuş Türkiye'deki çeşitli üniversitelerin eğitim fakültelerinde lisansüstü öğrenimlerine devam eden öğretmenlerin bilimsel araştırma bilgi, beceri ve tutumlarının geliştirilmesini amaçlayan bir proje bağlamında, projenin eğitim alanında araştırma yapmak için gerekli temel nitelikleri ne düzeyde geliștirdiğinin katılımcıların görüşlerine dayalı olarak incelenmesi amacıyla gerçekleștirilmiștir. Odak grup görüşmeleri sonucunda elde edilen bulgular projenin bilimsel araştırma bilgisi, bilimsel araştırma becerileri ve bilimsel araştırma yapmaya yönelik tutum-inanç olmak üzere üç temel boyutta katılımcıların araştırma yapma niteliklerini geliştirdiğini ortaya koymuştur. Katılımcıların çoğu bu projenin öncelikle bilimsel araştırma sürecinin çeşitli boyutlarını ve aşamalarını sistematik ve bütüncül bir çerçeve içerisinde öğrenmeleri konusunda araştırmacı olarak bilgi edinme bakımından gelişimlerine önemli bir katkı sağladığını ifade etmiş̧tir. Bulgulara göre, bu proje katılımcıların bilimsel araştırma yapma konusunda planlama, araştırma/proje önerisi yazma, veri analizi yapma, veri analizi programlarını kullanma, eleştirel ve yaratıcı düșünme, öz değerlendirme, iletișim ve grupla çalıșma becerilerini geliștirmelerine de katkıda bulunmuştur. Bilgi ve beceri boyutlarındaki kazanımlarına ek olarak, katılımcıların çoğunun projenin bilimsel araştırma yapma tutum ve inançlarını olumlu yönde etkilediğini ve proje boyunca sistematik, planlı ve nitelikli araştırma yapma yönünde bir bakış açısı geliştirdiklerini ifade ettiği görülmüştür. Birçok katılımcı projedeki kazanımlarından birinin bilimsel araştırmanın doğasını sorgulayıcı bir tutum geliştirmek olduğunu söylemiş, çeşitli boyutlarda öz yeterlik inançlarının yükseldiğini vurgulamış ve özellikle araştırma/proje önerisi yazma konusunda olumlu bir tutum geliştirdiklerini dile getirmiştir. Bilimsel araştırmalarda etik, veri analizi ve bu çerçevede veri analizi programlarının kullanımı ile bilimsel araştırma yapma sürecinde genel olarak teknoloji kullanımı açısından da katılımcılar proje kapsamında yüksek bir farkındalık ve olumlu tutum geliştirdiklerini söylemişlerdir. Benzer şekilde, birçok katılımcı araştırma sürecinin çeşitli bileşenlerine yönelik proje süresince uluslararası bir bakış açısı geliştirdiklerini vurgulamıştır. Ayrıca çok sayıda katılımcı disiplinlerarası bir bakış açısı ve tutum geliştirme firsatı elde etmenin araştırmacı olarak kendilerine önemli bir katkı sağladığından bahsetmiștir. Bunların yanı sıra, katılımcılar akademik yetkinlik, bilimsel araştırma sürecine yönelik disiplinli bir tutuma sahip olma, iletişime açık olma, etkili bir rehberlik sağlama ve yenilikleri takip etme tutumları bakımından da özellikle projede yer alan eğitmenleri rol model alma yoluyla bu konularda olumlu tutum geliştirdiklerini ifade etmişlerdir.

Araştırmadan elde edilen bulgulara göre katılımcı öğretmenlerin bilimsel araştırma bilgi, beceri, tutuminançlarının desteklenmesini amaçlayan bu eğitimi etkili buldukları sonucuna ulaşılabilir. Birçok çalışmanın öğretmenlerin araştırma bilgi, beceri ve tutumlarının iyileştirilmesine ihtiyaç duyulduğunu ortaya koyduğu göz önünde bulundurulduğunda (Ateș ve Yıldırım, 2015; Biçer ve diğ., 2013; Camuzcu Așiroğlu, 2016; Cerit Berber, 2013; Ekiz, 2006; Ekiz ve Yiğit, 2012; Korkmaz ve diğ., 2011; Küçükoğlu ve diğ., 2013; Nartgün ve diğ., 2008; Polat, 2014; Sarı, 2006; Şahin ve Arcagök, 2013; Taşdemir ve Taşdemir, 2011; Uçgun ve Ünal, 2015; Yenilmez ve Ata, 2012; Yıldırım, İlhan, Şekerci ve Sözbilir, 2014), katılımcıların bu proje süresince aldıkları eğitimi etkili bulmalarını sağlayan faktörlerin tartışılması önemlidir. Katılımcılar proje boyunca geliştirdikleri çeşitli bilgi, beceri ve inanç-tutum özelliklerinden bahsederken proje kapsamındaki çeşitli derslerde katıldıkları uygulamalı etkinliklerin ve grup çalışmalarının destekleyici rolü olduğunu belirtmişlerdir. Bu çerçevede, birçok katılımcı derslerin aktif öğrenme yöntemleri ile yapılandırılarak öğrenci motivasyonunu ve ilgisini artırmış olmasının önemine değinmiș, proje süresince eğitmenler tarafindan beyin firtınası, örnek olaylar ve sorular yoluyla zenginleştirilen çeşitli konulardaki küçük grup çalışmalarının kendilerine özellikle diğer katılımcılarla bilgi ve 
fikir alış verişi yapabilme, etkili bir iletişim kurma ve sosyalleşme, sahip oldukları kavram yanılgılarını düzeltme, eksik bilgi veya beceriye sahip olduklarını düşündükleri konularda yalnız olmayabileceklerini gözlemleme ve kaygı düzeylerinin azalmasını sağlama gibi birçok olanak sunarak gelişimlerini desteklediğini ifade etmiştir. Bunlara ek olarak, katılımcılar farklı disiplinlerde lisansüstü öğrenim gören bireylerle gerçekleştirilen küçük grup çalışmalarının disiplinlerarası bir bakış açısı geliştirmelerine de katkıda bulunduğunu belirtmişlerdir. Grup çalışmaları ile ilişkili olarak bazı katılımcılar ise oturma düzeninin sınıf içi etkileşimi kolaylaştırıcı şekilde düzenlenmesi yönünde önerilerde bulunmuştur. Katılımcıların çoğu özellikle veri analizi konusunda edindikleri bilgilerin proje süresince teknoloji destekli veri analizi programları yoluyla uygulamalı olarak pekiştirilmesinin veri analizi becerilerinin gelişimine güçlü bir etkisi olduğunu açıklamıştır. Bununla beraber, birçok katılımcı uygulamalı dersler kapsamında teknoloji destekli veri analizi programları ve literatür taramayı destekleyici programlar aracılığıyla bilimsel araştırma yapma sürecinin çeşitli aşamalarında teknoloji kullanımının önemini vurgulamıştır. Araştırmadan elde edilen bu sonuçların öğretmen eğitimi programlarında ve lisansüstü programlarda yer alan bilimsel araştırma yöntemleri dersinin öğretim süreçlerinin grup çalışmaları, aktif öğrenme yöntemleri, teknoloji destekli programlar ve uygulamalı etkinliklerin yaygınlaştırılması yoluyla iyileştirilmesine ve araştırma kültürünün geliştirilmesine 1şık tutacağı söylenebilir.

Alanyazındaki çeşitli araştırmalar öğretmen adaylarının veya lisansüstü öğrencilerin lisans/lisansüstü öğretim programlarında yer alan bilimsel araştırma yöntemleri dersine ilişkin tutum ve düşüncelerinin dersin kazanımları, içeriği, kullanılan öğretim yöntem ve teknikleri, ölçme değerlendirme teknikleri gibi çeşitli boyutlar açısından istenen düzeyde olumlu olmadığını ortaya koymakta ve iyileştirilmesi gerektiğine işaret etmektedir (Akgün, 2012; Ayaydın ve Kurtuldu, 2010; Çetin ve Dikici, 2014; Tomakin, 2007). Bu açıdan, yukarıda sunulan önerilerin hizmet öncesi öğretmen eğitimi ve lisansüstü eğitimin geliştirilmesine katkıda bulunacağı ve özellikle derslerin ana uygulayıcıları olan öğretmen eğitimcilerine 1şık tutacağı söylenebilir. Ayrıca bu önerilerin hizmet öncesi öğretmen eğitimi programlarından sorumlu YÖK'teki politika belirleyicilere de öğretmen yetiştirme lisans programlarında yer alan ve iki saatlik kuramsal bir ders olarak öngörülen Eğitimde Araştırma Yöntemleri dersinin iyileştirilmesi bakımından ışık tutacağı ifade edilebilir. Bu açıdan, meslek bilgisi kapsamındaki bu dersin haftalık ders saati artırılarak kazanımları ve içeriği gözden geçirilebilir ve aktif öğrenme yöntemleri ile zenginleştirilmesi teşvik edilerek hem kuramsal hem de uygulamalı bir ders olarak öngörülmesi sağlanabilir. Elde edilen sonuçlara dayalı olarak ayrıca öğretmen eğitimcilerinin akademik yetkinlik, bilimsel araştırma sürecine yönelik disiplinli bir tutuma sahip olma, iletişime açık olma, etkili bir rehberlik sağlama ve yenilikleri takip etme gibi tutum özellikleri bakımından öğretmen adaylarına veya lisansüstü öğrencilere rol model olmaları önerilebilir. Bunların yanı sıra, TÜBİTAK tarafından desteklenen bir proje kapsamında gerçekleştirilen bu durum çalışmasında, örneklemin 2006 yılı veya sonrasında kurulmuş Türkiye'deki çeşitli üniversitelerin eğitim fakültelerinde lisansüstü öğrenimlerine devam eden katılımcılardan seçildiği ve özellikle bu üniversitelerin öğretim üyesi sayısı ve niteliği, lisansüstü eğitim programlarının yeterliği, fiziksel ve teknolojik altyapı gibi çeşitli açılardan önemli ihtiyaçlara sahip oldukları göz önünde bulundurulduğunda elde edilen sonuçların önemli olduğu ve bu üniversitelerdeki mevcut lisansüstü eğitim uygulamalarına öneriler sunacağı söylenebilir. Bu açıdan, yeni kurulan üniversitelerin eğitim fakültelerindeki öğretim üyesi sayısının artırılması ve bilimsel araştırma yetkinliği/tutumu yüksek olan öğretim üyelerinin bilimsel araştırma yöntemleri ve benzeri dersleri vermeleri, öğretim üyelerinin bilimsel araştırma süreci konusunda öğrencileri teşvik edecek öğrenme yöntemlerini kullanmaları, sınıf içi etkileşimi teşvik etmeleri, öğrencilere iyi bir rehberlik sağlamaları, akademik ve teknolojik güncel gelişmeleri takip etmeleri ve ayrıca bu üniversitelerin fiziksel ve teknolojik altyapılarının zenginleştirilerek güçlendirilmesi önerilebilir. Araştırmanın örnekleminde yer alan ve lisansüstü öğrenimlerine devam eden katılımcıların lisans/lisansüstü ders deneyimlerine kıyasla daha kısa süreli bir eğitim olmasına rağmen bu eğitimden önemli derecede yararlandıklarını ifade etmelerinden hareketle, benzer nitelikteki eğitimlerin lisansüstü öğrenim görmeyen öğretmenler için de olumlu sonuçlar verebileceği söylenebilir. Bu ve benzeri eğitimlerin öğretmenleri araştırmacı öğretmen rolüyle teşvik ederek bilimsel araştırma bilgi, beceri, tutum-inançlarının desteklenmesi bakımından güçlendireceği ve bu sayede öğretmenlerin okul ya da sınıf içerisindeki durumları sistematik bir sorgulama ile daha iyi anlamalarına, okul temelli tabandan yapılanmaları güçlendirmelerine ve sınıf içerisindeki eğitim öğretim ihtiyaçlarına daha etkili çözümler geliştirebilmelerine katkıda bulunacağı ifade edilebilir.

Hizmet öncesi öğretmen eğitimine ve lisansüstü eğitime ek olarak, araştırmadan elde edilen sonuçların öğretmenlerin araştırma yapma bilgi, beceri ve tutumlarının desteklenmesi amacıyla MEB tarafından geliştirilecek hizmet içi eğitim programlarına da 1şı tutabileceği düşünülmektedir. Beceri ve tutum-inanç gibi özelliklerin bireylerde uzun bir süre içerisinde geliştiği göz önünde bulundurulduğunda araştırmadan elde edilen sonuçlara göre katılımcıların proje süresince geliştirdiklerini ifade ettikleri beceri ve tutum-inanç özelliklerinin süreklilik içerisinde ve uzun süreli olarak desteklenmesi önemlidir. Bu araştırmada incelenen proje TÜBİTAK tarafından belirlenen bir süre çerçevesinde yoğunlaştırılmış bir program ile beş gün içerisinde gerçekleştirilmiş olup gelecekte düzenlenecek benzer nitelikteki hizmet içi eğitim programlarının daha uzun bir süre içerisinde ve projenin uygulanması önerilebilir. 


\section{Kaynakça/References}

Akgün, L. (2012). Bilimsel araştırma yöntemleri dersine ilişkin öğretmen adaylarının alg1 ve beklentileri. Ballkesir Üniversitesi Sosyal Bilimler Enstitüsü Dergisi, 15(27), 21-30.

Ateş, S. (2005). Öğretmen adaylarının değişkenleri belirleme ve kontrol etme yeteneklerinin geliştirilmesi. Gazi Eğitim Fakültesi Dergisi, 25(1), 21-39.

Ateş, S. ve Yıldırım, K. (2015). Türk öğretmenlerin gözüyle eğitim araştırmalarının uygulamaya yansıma durumu. Mustafa Kemal Üniversitesi Sosyal Bilimler Enstitüsü Dergisi, 12(29), 110-132.

Ayaydın, A. ve Kurtuldu, M. K. (2010). Güzel sanatlar eğitimi bölümü öğrencilerinin bilimsel araştırma yöntemleri dersine ilişkin tutumları. Abant İzzet Baysal Üniversitesi Dergisi, 10(2), 1-8.

Aydın, R., Şahin, H. ve Topal, T. (2008). Türkiye'de ilköğretime sınıf öğretmeni yetiştirmede nitelik arayışları. TSA, 12(2), 119-142.

Azar, A. (2011). Türkiye'de öğretmen eğitimi üzerine bir söylem: Nitelik mi, nicelik mi? Journal of Higher Education and Science, 1(1), 36-38. doi:10.5961/jhes.2011.004.

Babkie, A. M., \& Provost, M. C. (2004). Teachers as researchers. Intervention in School and Clinic, 39(5), 260268. doi:10.1177/10534512040390050201.

Becker, B. J., Kennedy, M. M., \& Hundersmarck, S. (2003, Nisan). Communities of scholars, research, and debates about teacher quality. Sözel bildiri, American Educational Research Association Konferans1 (AERA), Chicago.

Biçer, M., Bozkırlı, K. Ç. ve Er, O. (2013). Türkçe öğretmeni adaylarının bilimsel araştırmaya yönelik tutumlarının değerlendirilmesi. A.Ü. Türkiyat Araştırmaları Enstitüsü Dergisi, 50, 327-342 doi:10.14222/Turkiyat33.

Bogdan, R. C., \& Biklen, S. K. (2007). Qualitative research for education: An introduction to theory and methods $\left(5^{\text {th }}\right.$ ed.). The USA: Pearson Education.

Broekkamp, H., \& van Hout-Wolters, B. (2007). The gap between educational research and practice: A literature review, symposium, and questionnaire. Educational Research and Evaluation: An International Journal on Theory and Practice, 13(3), 203-220. doi:10.1080/13803610701626127.

Büyüköztürk, Ş. (1997). Araştırmaya yönelik kayg1 ölçeğinin geliştirilmesi. Eğitim Yönetimi, 3(4), 453-464.

Büyüköztürk, Ş. (1999). İlköğretim okulu öğretmenlerinin araştırma yeterlikleri. Kuram ve Uygulamada Eğitim Yönetimi, 18, 257-269.

Büyüköztürk, Ş., Kılıç Çakmak, E., Akgün, Ö. E., Karadeniz, Ş. ve Demirel, F. (2012). Bilimsel araştırma yöntemleri. Ankara: Pegem Akademi.

Camuzcu Aşiroğlu, S. (2016). Öğretmen adaylarının bilimsel araştırmaya yönelik tutumları ile bilimsel araştırma dersindeki başarıları arasındaki ilişkinin incelenmesi. Uşak Üniversitesi Eğitim Araştırmaları Dergisi, 2(2), 72-84. doi:10.29065/usakead.232429.

Cerit Berber, N. (2013). Ortaöğretim öğrencilerinin ve öğretmenlerinin eğitim araştırmalarına bakışı. Buca Eğitim Fakültesi Dergisi, 36, 142-159.

Cochran-Smith, M., \& Fries, K. (2008). Research on teacher education: changing times, changing paradigms. İçinde M. Cochran-Smith, S. Feiman-Nemser, \& D. J. McIntyre (Ed.), Handbook of research on teacher education: Enduring questions in changing contexts (s. 1050-1093). New York, NY: Routledge/Taylor Francis and The Association of Teacher Educators.

Cochran-Smith, M., \& Lytle, S. L. (1990). Research on teaching and teacher research: The issues that divide. Educational Researcher, 19(2), 2-11. doi:10.3102/0013189X019002002.

Cochran-Smith, M., \& Lytle, S. L. (1993). Inside/outside teacher research and knowledge. New York, NY: Teachers College, Columbia University. 
Cochran-Smith, M., \& Lytle, S. L. (1998). Teacher research: The question that persists. International Journal of Leadership in Education Theory and Practice, 1(1), 19-36. doi:10.1080/1360312980010103

Cochran-Smith, M., \& Lytle, S. L. (1999). The teacher research movement: A decade later. Educational Researcher, 28(7), 15-25. doi:10.3102/0013189X028007015

Crawford, K., \& Adler, J. (1996). Teachers as researchers in mathematics education. İçinde A. J. Bishop, K. Clements, C. Keitel, J. Kilpatrick, \& C. Laborde (Ed.), International handbook of mathematics education (s. 1187-1205). Dordrecht, The Netherlands: Kluwer Academic Publishers.

Creswell, J. W. (2013). Qualitative inquiry and research design: Choosing among five approaches (3 ${ }^{\text {rd }}$ ed.). Thousand Oaks, CA: Sage Publications, Inc.

Çakıroğlu, E. ve Çakıroğlu, J. (2003). Reflections on teacher education in Turkey. European Journal of Teacher Education, 26(2), 253-264.

Çepni, S. ve Küçük, M. (2003). Eğitim araştırmalarının fen bilgisi öğretmenlerinin uygulamaları üzerindeki etkilerinin belirlenmesi: Bir örnek olay çalışması. Eğitim Araştırmaları Dergisi, 4(12), 75-84.

Çetin, A. ve Dikici, R. (2014). Eğitim bilimlerinde araştırma yöntemleri dersinin etkililiği. Kastamonu Ĕgitim Dergisi, 22(3), 981-994.

Darling-Hammond, L. (2010). Evaluating teacher effectiveness: How teacher performance assessments can measure and improve teaching.

https://edpolicy.stanford.edu/sites/default/files/publications/evaluatingteacher-effectiveness_0.pdf adresinden elde edildi.

Darling-Hammond, L., \& Sykes, G. (2003). Wanted: A national teacher supply policy for education: The right way to meet the "highly qualified teacher" challenge. Education Policy Analysis Archives, 11(33), 1-55. doi:10.14507/epaa.v11n33.2003.

Darling-Hammond, L., \& Youngs, P. (2002). Defining "highly qualified teachers": What does "scientificallybased research" actually tell us? Educational Researcher, 31(9), 13-25. doi:10.3102/0013189X031009013

Day, C. (2013). Teacher quality in the twenty first century: New lives, old truths. İçinde X. Zhu, \& K. Zeichner (Ed.), Preparing teachers for the $21^{\text {st }}$ century (s. 21-38). Berlin Heidelberg: Springer.

Ekiz, D. (2006). Primary school teachers' attitudes towards educational research. Educational Sciences: Theory \& Practice, 6(2), 395-402.

Ekiz, D. ve Yiğit, N. (2012). Öğretmen adaylarının eğitim araştırmalarının amaç ve çeşitleri hakkındaki görüşlerinin incelenmesi. Sakarya Üniversitesi Eğitim Fakültesi Dergisi, 23(Mayıs, 2012), 3-20.

Elliot, J. (1993). Three perspectives on coherence and continuity in teacher education. İçinde J. Elliot (Ed.), Reconstructing teacher education (s. 15-19). London: Falmer Press.

European Commission (2013). Supporting teacher competence development for better learning outcomes. http://ec.europa.eu/assets/eac/education/experts-groups/2011-2013/teacher/teachercomp_en.pdf adresinden elde edildi.

Goldhaber, D. (2007). Everyone's doing it, but what does teacher testing tell us about teacher effectiveness? The Journal of Human Resources, 42(4), 765-794.

Gopinathan, S., Tan, S., Yanping, F., Devi, L., Ramos, C., \& Chao, E. (2008). Transforming teacher education: Redefined professionals for $21^{\text {st }}$ century schools. https://www.nnstoy.org/download/preparation/Transforming\%20Teacher\%20Education\%20Report.pdf adresinden elde edildi.

Hanushek, E. A., \& Rivkin, S. G. (2010). Generalizations about using value-added measures of teacher quality. The American Economic Review, 100(2), 267-271.

Hargreaves, A. (1995). Revisiting voice. Educational Researcher, 25, 12-19. doi:10.3102/0013189X025001012 
Iliško, D., Ignatjeva, S., \& Mičule, I. (2010). Teachers as researchers: Bringing teachers' voice to the educational landscape. Journal of Teacher Education for Sustainability, 12(1), 51-65. doi:10.2478/v10099-009-0046-X

Kincheloe, J. L. (2012). Teachers as researchers: Qualitative inquiry as a path to empowerment (Classic ed.). London and New York, NY: Routledge.

Korkmaz, Ö., Şahin, A. ve Yeşil, R. (2011). Öğretmenlerin bilimsel araştırmalara ve araştırmacılara ilişkin düşünceleri. Kuramsal Eğitimbilim, 4(2), 109-127.

Korthagen, F. A. J. (2007). The gap between research and practice revisited. Educational Research and Evaluation, 13(3), 303-310. doi:10.1080/13803610701640235

Kuzu, A. (2009). Öğretmen yetiştirme ve mesleki gelişimde eylem araştırması. Uluslararası Sosyal Araştırmalar Dergisi, 2(6), 425-433.

Küçük, M. ve Çepni, S. (2005). Implementation of an action research course program for science teachers: A case for Turkey. The Qualitative Report, 10(2), 190-207.

Küçükoğlu, A., Taşgın, A. ve Çelik, N. (2013). Öğretmen adaylarının bilimsel araştırma sürecine ilişkin görüşleri üzerine bir inceleme: Eğitim bilimleri bölümü örneği. TSA, 17(3), 11-24.

Kvale, S. (2007). Doing interviews (1 ${ }^{\text {st }}$ ed.). London: Sage Publications, Inc.

Long, D., \& Riegle, R. P. (2002). Teacher education: The key to effective school reform. Westport, CT: Bergin \& Garvey.

Lytle, S. L., \& Cochran-Smith, M. (1992). Teacher research as a way of knowing. Harvard Educational Review, 62(4), 447-475.

Marshall, C., \& Rossman, G. B. (2011). Designing qualitative research (5 ${ }^{\text {th }}$ ed.). Thousand Oaks, CA: Sage Publications, Inc.

Maxwell, J. A. (2013). Qualitative research design: An interactive approach ( ${ }^{\text {rd }}$ ed.). Thousand Oaks, CA: Sage Publications, Inc.

May, W. T. (1993). "Teachers as researchers" or action research: What is it, and what good is it for art education? Studies in Art Education, 34(2), 114-126.

McIntyre, D. (2005). Bridging the gap between research and practice. Cambridge Journal of Education, 35(3), 357-382. doi: 10.1080/03057640500319065

MEB (Millî Eğitim Bakanlığı). (2006). TEDP: Temel eğitime destek projesi “öğretmen eğitimi bileşeni”: Ögretmenlik mesleği genel yeterlikleri. http://oygm.meb.gov.tr/meb_iys_dosyalar/2017_12/13161921_YYretmenlik_MesleYi_Genel_YETERLY KLERi_onaylanan.pdf adresinden elde edildi.

MEB (Millî Eğitim Bakanlığı). (2017). Öğretmenlik mesleği genel yeterlikleri. http://oygm.meb.gov.tr/meb_iys_dosyalar/2017_12/11115355_YYRETMENLYK_MESLEYY_GENEL_Y ETERLYKLERY.pdf adresinden elde edildi.

Metin, M. (2015). Kuramdan uygulamaya ĕgitimde bilimsel araştırma yöntemleri (2. Baskı). Ankara: Pegem.

Miles, M. B., \& Huberman, A. M. (1994). Qualitative data analysis: An expanded sourcebook (2 ${ }^{\text {nd }}$ ed.). Thousand Oaks, CA: Sage Publications, Inc.

Nartgün, Z., Uluman, M., Akın, Ç., Çelik, T. ve Çevik, C. (2008, Eylül). Öğretmen adaylarının bilimsel araştırma öz yeterliklerinin incelenmesi. Sözel bildiri, 17. Eğitim Bilimleri Kongresi, Sakarya.

Nye, B., Konstantopoulos, S., \& Hedges, L. (2004). How large are teacher effects? Educational Evaluation and Policy Analysis, 26, 237-257. doi:10.3102/01623737026003237

OECD (Organisation for Economic Co-Operation). (2005). Teachers matter: Attracting, developing and retaining effective teachers. https://www.oecd.org/edu/school/34990905.pdf adresinden elde edildi.

Patton, M. Q. (1990). Qualitative evaluation and research methods (2 ${ }^{\text {nd }}$ ed.). Newbury Park, CA: Sage Publications, Inc. 
Polat, M. (2014). Ĕ̆itim fakültesi öğrencilerinin bilimsel araştırmaya yönelik tutumları. Pamukkale Üniversitesi Sosyal Bilimler Enstitüsü Dergisi, 18, 77-90.

Postholm, M. B. (2009). Research and development work: Developing teachers as researchers or just teachers? Educational Action Research, 17(4), 551-565. doi:10.1080/09650790903309425

Rice, J. K. (2003). Teacher quality: Understanding the effectiveness of teacher attributes. Washington, D.C.: Economic Policy Institute.

Robinson, V. (2003). Teachers as researchers: A professional necessity? SET: Research Information for Teachers, 1, 27-29.

Sar1, M. (2006). Teacher as a researcher: Evaluation of teachers' perceptions on scientific research. Educational Sciences: Theory \& Practice, 6(3), 880-887.

Şahin, Ç. ve Arcagök, S. (2013). İlköğretim öğretmenlerinin eğitim araştırmalarına yönelik yaklaşımları. Bilgisayar ve Eğitim Araştırmaları Dergisi, 1(2), 1-20.

Taşdemir, M. ve Taşdemir, A. (2011). Öğretmen adaylarının bilimsel araştırmaları inceleme yeterlikleri. Selçuk Üniversitesi Sosyal Bilimler Enstitüsü Dergisi, 26, 343-353.

Tomakin, E. (2007). Bilimsel araştırma yöntemleri dersinin etkin öğretilmesinin incelenmesi. Kazım Karabekir Ĕ̌itim Fakültesi Dergisi, 16, 37-65.

Uçgun, D. ve Ünal, E. (2015). Türkçe ve sınıf öğretmenlerinin eğitim araştırmalarına yönelik tutumlarının incelenmesi. Erzincan Üniversitesi Sosyal Bilimler Enstitüsü Dergisi, 9(2), 85-94.

Vanderlinde, R., \& van Braak, J. (2010). The gap between educational research and practice: Views of teachers, school leaders, intermediaries and researchers. British Educational Research Journal, 36(2), 299-316. doi:10.1080/01411920902919257

van Zee, E. H. (1998). Preparing teachers as researchers in courses on methods of teaching science. Journal of Research in Science Teaching, 35(7), 791-809. doi:10.1002/(SICI)1098-2736(199809)35:7<791::AIDTEA8>3.0.CO;2-G

Wayne, A. J., \& Youngs, P. (2003). Teacher characteristics and student achievement gains: A review. Review of Educational Research, 73(1), 89-122. doi:10.3102/00346543073001089

Yenilmez, K. ve Ata, A. (2012, Haziran). Matematik öğretmeni adaylarının bilimsel araştırmalara yönelik tutumlarının incelenmesi. Sözel bildiri, X. Ulusal Fen Bilimleri ve Matematik Eğitimi Kongresi, Niğde.

Yıldırım, A. (2011). Öğretmen eğitiminde çatışma alanları ve yeniden yapılanma. Uluslararası Eğitim Programları ve Öğretim Çalışmaları Dergisi, 1(1), 1-17.

Yıldırım, A. (2013). Türkiye'de öğretmen eğitimi araştırmaları: Yönelimler, sorunlar ve öncelikli alanlar. Ĕ̆gitim ve Bilim, 38(169), 175-191.

Yıldırım, A. (2018). Prof. Dr. Ali Yıldırım ile Türkiye'de öğretmen yetiştirme süreci üzerine/Yazar: TEDMEM. https://tedmem.org/dosya-konusu/prof-dr-ali-yildirim-ile-turkiyede-ogretmen-yetistirme-sureci-uzerine adresinden elde edildi.

Yıldırım, A., İlhan, N., Şekerci, A. R. ve Sözbilir, M. (2014). Fen ve teknoloji öğretmenlerinin eğitim araştırmalarını takip etme, anlama ve uygulamalarda kullanma düzeyleri: Erzurum ve Erzincan örneği. Kastamonu Eğitim Dergisi, 22(1), 81-100.

Yıldırım, A. ve Şimşek, H. (2018). Sosyal bilimlerde nitel araştırma yöntemleri (11. Baskı). Ankara: Seçkin Yayınc1lik.

Yin, R. K. (2014). Case study research: Design and methods ( $5^{\text {th }}$ ed.). Thousand Oaks, CA: Sage Publications.

Zeichner, K. M. (1983). Alternative paradigms of teacher education. Journal of Teacher Education, 34(3), 3-9. doi:10.1177/00224871830340030 